Genetic and environmental risk factors, informative subtypes and putative endophenotypes in major depressive disorder

\author{
Ph.D. Thesis
}

Timea Anna Bianchi-Rimay, M.D.

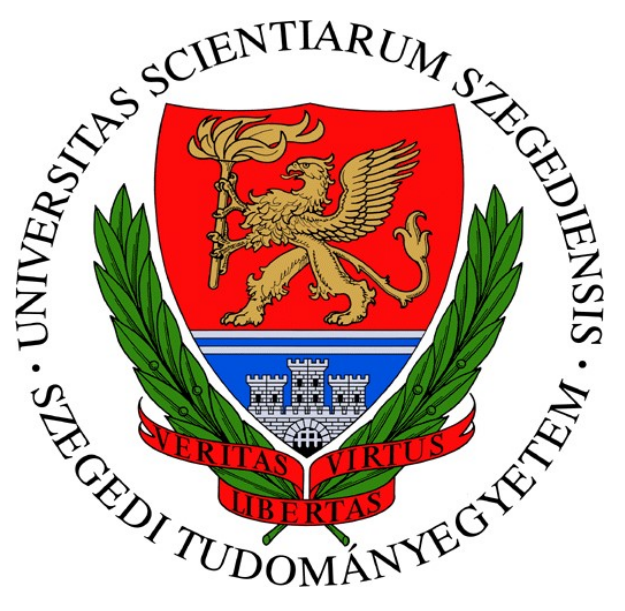

SZEGED

2016 


\title{
Genetic and environmental risk factors, informative subtypes and putative endophenotypes in major depressive disorder
}

Ph.D. Thesis

\section{Timea Anna Bianchi-Rimay, M.D.}

\author{
Faculty of Medicine \\ University of Szeged
}

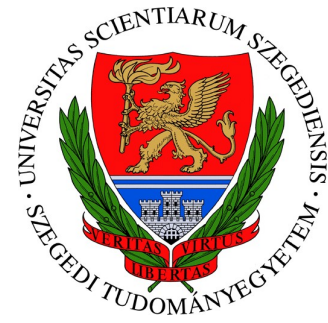

Supervisors:

Ágnes Vetró, M.D. Ph.D.

Krisztina Kapornai, M.D. Ph.D.

Department of Child- and Adolescent Psychiatry

Department of Pediatrics and Child Health Center

\section{SZEGED}

2016 


\section{PUBLICATIONS RELATED TO THE THESIS}

I. J.S. Strauss, N.L. Freeman, S.A. Shaikh, A. Vetro, E. Kiss, K. Kapornai, G. Daroczi, T. Rimay, V.O. Kothencne, E. Dombovari, E. Kaczvinszky, Zs. Tamas, I. Baji, M. Besnyo, J. Gádoros, V. DeLuca, C.J. George, E. Dempster, C.L. Barr, M. Kovacs, J.L. Kennedy (2010). No association between oxytocin or prolactin gene variants and childhood-onset mood disorders. Psychoneuroendocrinology 35 (9): 1422-1428. [IF:5,168]

II. T. Rimay, I. Benak, E. Kiss, I. Baji, A. Feher, A. Juhasz, J. Strauss, J. Kennedy, C. Barr, M. Kovacs, A. Vetro, K. Kapornai and the International Consortium of Childhood-Onset Mood disorders (2015). BDNF Val66Met Polymorphism and Stressful Life Events in Melancholic Childhood-Onset Depression. Psychiatric Genetics 25:249-255. [IF:1.94].

III. A. Vetro, I. Baji., I. Benak, M. Besnyo, J. Csorba, G. Daroczy, E. Dombovari, E. Kiss, J. Gadoros, E. Kaczvinszky, K. Kapornai, L. Mayer, T. Rimay, D. Skultety, K. Szabo, Zs. Tamas, J. Szekely, M. Kovacs (2009). "Risk factors for childhood depression"-research design, implementation, proceedings: history of 13 years: experience in grant preparation, writing, organization in connection with an American NIMH Grant. Psychiatria Hungarica 24 (1): 6-17.

\section{ABSTRACTS RELATED TO THE THESIS}

I. T. Rimay, G. Daroczi, E. Kovacs, I. Benak, A. Feher, A. Juhasz, A. Vetro and M. Kovacs (2010). Preliminary study investigating the interferon gamma $+874 \mathrm{~T} / \mathrm{A}$ polymorphism and the somatic type of depression. European Neuropsychopharmacology 20:S225.

II. T. Rimay, G. Daróczi, E. Kovács, I. Benák, Á. Fehér, A. Juhász, Á. Vetró, M. Kovacs: Preliminary study investigating the interferon gamma +874 T/A polymorphism and the somatic type of depression 23rd European College of Neuropsychopharmacology Congress Amsterdam, The Netherlands, 28 August-1 September 2010. p.:48. 
III. T. Rimay, G. Daróczi, E. Kovács, I. Benák, Á. Fehér, A. Juhász, Á. Vetró, M. Kovacs: BDNF Val66Met polymorphism in depressed children and their siblings 4th International Romanian-Hungarian Psychiatric Congress, Miercurea Ciuc, Romania, 24-26. June 2010. p.:61.

IV. T. Rimay, G. Daróczi, E. Kovács, I. Benák, Á. Fehér, A. Juhász, Á. Vetró, M. Kovacs: Interferon gamma $+874 \mathrm{~T} / \mathrm{A}$ polymorphism in childhood onset depression Hungarian Child Neurology, Child Neurosurgery and Child and Adolescent Psychiatry Association 35rd Annual Meeting, Szeged, Hungary, 27-29. May 2010. p.:16

V. T. Rimay, G. Daróczi, E. Kovács, I. Benák, Á. Fehér, A. Juhász, Á. Vetró, M. Kovacs: Brainderived neurotrophic factor Val66Met polymorphism in depressed children and adolescent population Clinical Neurogenetics from Diagnosis to Therapy, Hungarian Society of Clinical Neurogenetics, VIIIth Conference, Visegrád, Hungary, 4-5. December 2009. p.:38.

VI. A. Vetró, J. Gádoros, I. Baji, K. Kapornai, E. Kiss, T. Rimay, L. Mayer, M. Kovacs: What is News in Childhood Onset Depression in Hungary International Conference Sponsored by European Society for Child and Adolescent Psychiatry, Budapest, Hungary, 22-26. August 2009. p.:23.

VII. T. Rimay, G. Daróczi, E. Kovács, I. Benák, Á. Fehér, A. Juhász, Á. Vetró, M. Kovacs: Brain-derived neurotrophic factor Val66Met polymorphism in depressed children and their siblings Hungarian Child Neurology, Child Neurosurgery and Child and Adolescent Psychiatry Association 34rd Annual Meeting, Kecskemét, Hungary, 23-25. April 2009. p.:76. 


\section{ABSTRACT}

Introduction and hypotheses: Gene polymorphisms that are suspected of playing a role in the development of childhood onset depression are examined in our work. Furthermore, we examine symptoms or symptom groups that can be considered as homogeneous types or endophenotypes of depression, and can be associated with the investigated genotypes or alleles. Oxytocin (OXT) and prolactin (PRL) are neuropeptide hormones that interact with the serotonin system and are involved in the stress response and social affiliation. In human studies, serum OXT and PRL levels have been associated with depression and related phenotypes. Both brain-derived neurotrophic factor $(B D N F)$ polymorphisms and interferon-gamma $+874 \mathrm{~T} / \mathrm{A}$ polymorphism have been examined for their contribution to depression with equivocal results. More homogeneous phenotypes might be used to improve our understanding of genetic liability to depression.

The aim of our work was to 1) determine if single nucleotide polymorphisms (SNPs) at the loci for $O X T$ and $P R L$ and their receptors, $O X T R$ and PRLR, were associated with childhood-onset mood disorders (COMD). 2) to test for association between $B D N F$ Val66Met polymorphism and childhood onset melancholic depression and 3) to investigate the interferon-gamma $+874 \mathrm{~T} / \mathrm{A}$ polymorphism and the somatic type of depression.

We also examined the interactive effects of stressful life events (SLE) and the Val66Met polymorphism on the risk of childhood onset melancholic depression.

Materials and Methods: Using 678 families in a family-based association design, we genotyped 16 SNPs at $O X T, P R L, O X T R$ and $P R L R$ to test for association with COMD. Examining the $B D N F$, in the preliminary studies and the following case-control studies, first subsets, then a sample of 583 depressed probands were involved (55 from the somatic type of depression, 162 of the melancholic subtype). Diagnoses were derived via the Interview Schedule for Children and Adolescents - Diagnostic Version and life event data were collected by means of an Intake General Information Sheet. 
Results: No significant associations were found for SNPs in the OXTR, PRL, or PRLR genes. Two of three SNPs of the $O X T$ gene were associated with COMD ( $\mathrm{p}=0.02)$, significant after spectral decomposition, but were not significant after additionally correcting for the number of genes.

In the „preliminary $B D N F$ study”, regarding the melancholic subtype, $B D N F$ Val66Val genotype had a significantly higher frequency in the melancholic depressed group than in the controls $(p=0.024)$. In the study examining the whole sample of depressed probands, $27.8 \%$ of the participants met criteria for melancholy. In the melancholic group the proportion of the females was higher $(53.1 \%)$, though there were more males in the overall depressed sample. We detected no significant differences in genotype or allele frequency between the melancholic and the nonmelancholic depressed group. BDNF Val66Met polymorphism and stressful life event interaction was not significantly associated with the melancholy outcome.

Regarding the association of somatic type of depression and the interferon-gamma $+874 \mathrm{~T} / \mathrm{A}$ polymorphism, the frequencies of the A allele containing genotypes were higher in the somatic subtype, than in the comparison group, without statistically significant difference (T/A: SB (sickness behaviour) group: 60.0\%, comparison group: $51.1 \%$; A/A: SB group: $21.8 \%$, comparison group: $13.3 \% ; \mathrm{p}=0.122$ ). The comparison of allele frequencies also did not reveal statistically significant differences (T: SB group: 48.2\%, comparison group: $61.1 \%$; A: SB group: $51.8 \%$, comparison group: $38.9 \%$; $>00.1$ ).

Conclusion: In our study, females were more prone to develop the early-onset melancholic phenotype. The present work is the first genetic analysis to examine the association between variants in the oxytocin and prolactin neuroendocrine genes and depression with onset in childhood. To our knowledge, this is also the first study to investigate the differentiating effect of the genotype and the $\mathrm{G} \times \mathrm{E}$ interaction on melancholic phenotype in a large sample of depressed young patients. We didn't find association between the melancholic subtype of major depression and the BDNF genotype and stressful life event interaction and the somatic subtype of childhood-onset major depression and the interferon-gamma $+874 \mathrm{~T} / \mathrm{A}$ polymorphism in this large sample, which is representative to the Hungarian clinic-referred population of depressed youths. 


\section{List of abbreviations}

\begin{tabular}{|c|c|}
\hline AVP & Arginine Vasopressin \\
\hline AVPR1B & Vasopressin V1b Receptor Gene \\
\hline BED & Best Estimate Diagnosis \\
\hline BDNF & Brain- Derived Neurotrophic Factor \\
\hline CDI & Children Depression Inventory \\
\hline COD & Childhood-Onset Depression \\
\hline COMD & Childhood-Onset Major Depression \\
\hline $\mathrm{D}$ & Depression \\
\hline DNA & Deoxyribose Nucleic Acid \\
\hline DSC & Depressive Symptom Checklist \\
\hline DSM-III & $\begin{array}{l}\text { Diagnostic and Statistical Manual of } \\
\text { Mental Disorders 3rd Edition }\end{array}$ \\
\hline DSM-IV & $\begin{array}{l}\text { Diagnostic and Statistical Manual of } \\
\text { Mental Disorders 4th Edition }\end{array}$ \\
\hline FET & Fisher's Exact Test \\
\hline $\mathrm{G} \times \mathrm{E}$ & Gene-Environment Interaction \\
\hline GIS & General Information Sheet \\
\hline HPA & Hypothalamic-Pituitary-Adrenal \\
\hline IFN- $\gamma$ & Interferon-gamma \\
\hline IGIS & Intake General Information Sheet \\
\hline IGR & Intergenic Region \\
\hline ISCA & $\begin{array}{l}\text { Interview Schedule for Children and } \\
\text { Adolescents }\end{array}$ \\
\hline ISCA-D-PL & $\begin{array}{l}\text { Interview Schedule for Children and } \\
\text { Adolescents Diagnostic Version Present } \\
\text { and Lifetime }\end{array}$ \\
\hline LD & Linkage Disequilibrium \\
\hline LRS & Likelihood Ratio Test Statistic \\
\hline
\end{tabular}




\begin{tabular}{|c|c|}
\hline $\mathrm{MCN}$ & Magnocellular Neuron \\
\hline MDD & Major Depressive Disorder \\
\hline MEL & Melancholic \\
\hline MFU & Mail-Follow-up Test Package \\
\hline NIMH & National Institute of Mental Health \\
\hline NMEL & Nonmelancholic \\
\hline OXT & Oxytocin \\
\hline OXTR & Oxytocin Receptor \\
\hline PCR & Polymerase Chain Reaction \\
\hline POE & Parent-of-origin Effects \\
\hline PRL & Prolactin \\
\hline PRLR & Prolactin Receptor \\
\hline RR & Relative Risk \\
\hline $\mathrm{SD}$ & Standard Deviation \\
\hline SLE & Stressful Life Event \\
\hline SNP & Single Nucleotide Polymorphism \\
\hline \multirow{2}{*}{ SNPSpD } & Single Nucleotide Polymorphism \\
\hline & Spectral Decomposition \\
\hline SR-GIS & $\begin{array}{l}\text { General Information Sheet-Short } \\
\text { version }\end{array}$ \\
\hline STOD & Somatic Type of Depression \\
\hline $\operatorname{Tr}$ & Transmitted \\
\hline TDT & Transmission Disequilibrium Test \\
\hline Un & Untransmitted \\
\hline \multirow{2}{*}{ 5-HTTLPR } & Serotonin-Transporter-Linked \\
\hline & Polymorphic Region \\
\hline
\end{tabular}




\section{Table of contents}

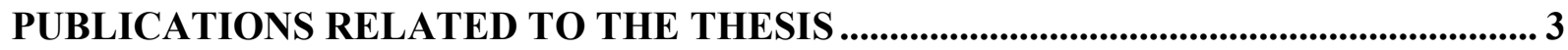

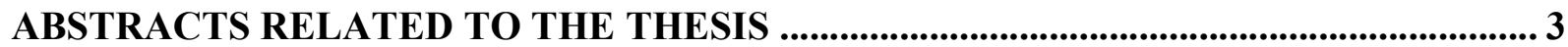

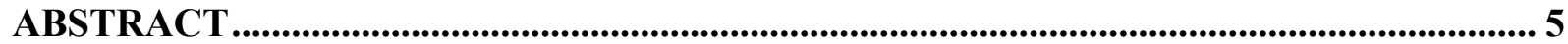

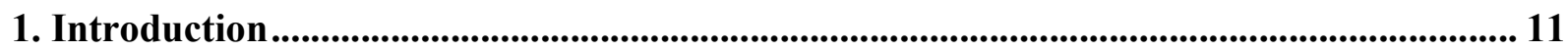

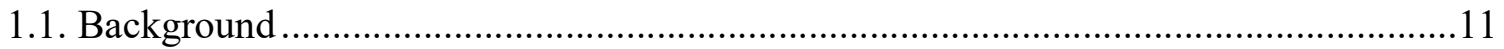

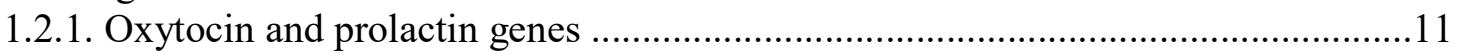

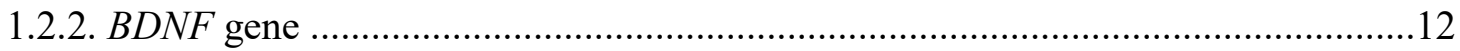

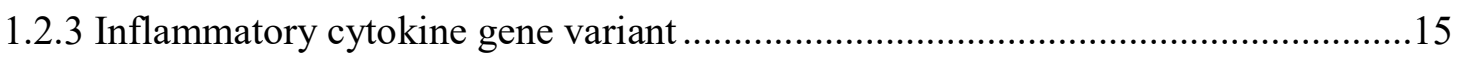

1.3. Factors which may influence the link between genetic liability and depression...........15

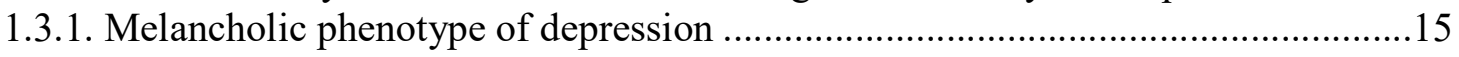

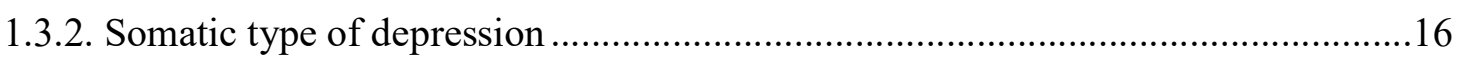

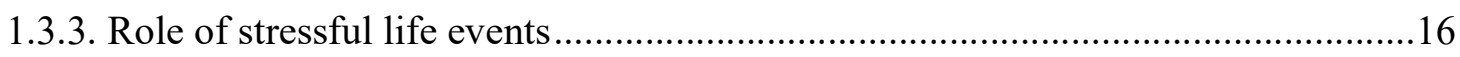

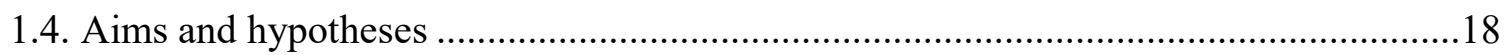

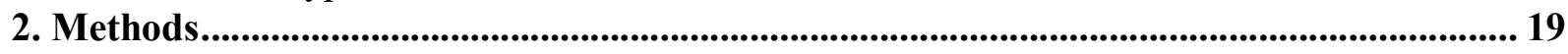

2.1. Participants, enrolment and assessment procedures in the Childhood Onset Major Depression study

2.1.1. Study 1. Investigating the oxytocin or prolactin gene variants.............................22

2.1.2. Preliminary studies testing the $B D N F$ Val66Met polymorphism in depressed children and their unaffected siblings.

2.1.3. Study 2. Investigating the melancholic and the nonmelancholic depressed groups 23

2.1.4. Study 3. Investigating the interferon-gamma $+874 \mathrm{~T} / \mathrm{A}$ polymorphism .24

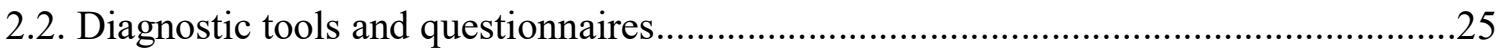

2.2.1. Intake General Information Sheet for Children and Adolescents (IGIS) ...............25

2.2.2. Interview Schedule for Children and Adolescents - Diagnostic Version Present and

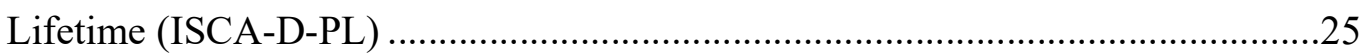

2.2.3. Children Depression Inventory-Short Version (CDI-Short Form) ........................26

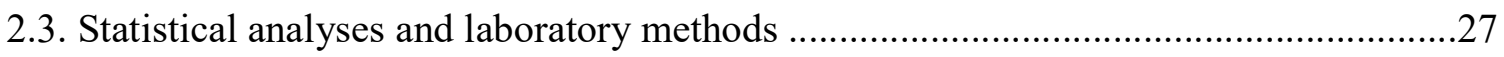

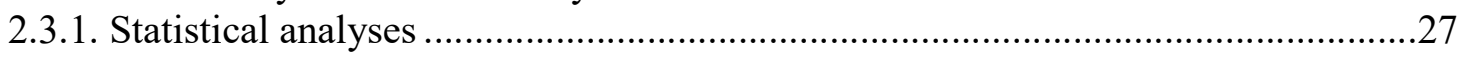

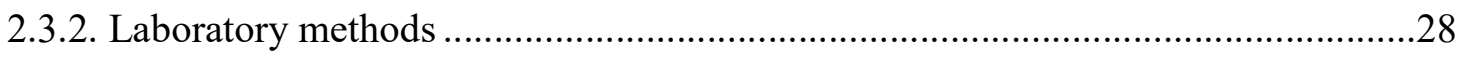




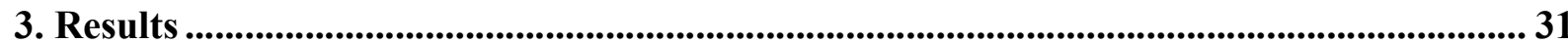

3.1. Investigating the $O X T, O X T R, P R L$, and $P R L R$ genes in child and youth depression...31

3.2. The preliminary studies investigating the role of $B D N F$ Val66Met polymorphism in childhood onset depression....

3.3. BDNF Val66Met genotype and allele distributions in melancholic and non-melancholic depressed participants and examining whether the past exposure to SLEs interacts with $B D N F$ to predict the melancholic subtype....

3.4. Investigating the association between interferon gamma $+874 \mathrm{~T} / \mathrm{A}$ polymorphism and the somatic type of depression

4. Discussion

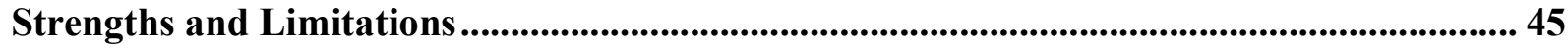

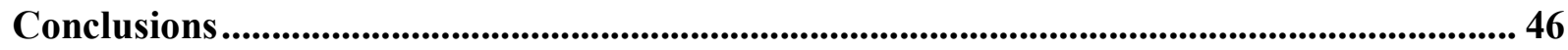

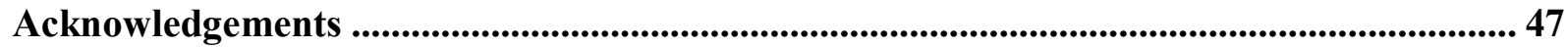

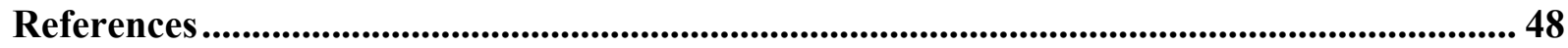

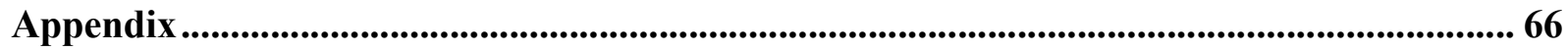




\section{Introduction}

\subsection{Background}

Major depressive disorder (MDD) is a major public health problem representing the leading cause of disability in developed countries and the fourth leading cause of disability worldwide. Lifetime risk for developing MDD is estimated to be approximately 15\% (Kessler et al., 2003). Mortality risk of depressed patients is two times greater than that of the general population due to direct (suicide) and indirect causes (Cuijpers and Smit, 2002).

It is well documented that MDD is most likely resulted from complex interactions of genetic, epigenetic, environmental and developmental factors, nevertheless the exact mechanisms underlying the disease are still largely unknown (e.g. Ebmeier et al., 2006). There is fairly consistent evidence that childhood onset depression (COD) has familial determinants (Rice et al., 2002). For example, in a large twin study the hereditability for MDD was $29 \%$ in males and $42 \%$ in females, respectively (Kendler et al., 2006). Levinson (2006) estimated the genetic contribution to the development of MDD as $40-50 \%$.

To achieve the goal of developing more effective treatment for MDD, a greater understanding of the neurobiology of psychopathology and the identification of the risk and resilience factors are needed.

\subsection{Putative genetic liability to depression}

\subsubsection{Oxytocin and prolactin genes}

Molecular genetic studies of depression-related phenotypes in paediatric samples are relatively few in number, with many focused on serotonin system genes. Genetic association studies of variants in the serotonin transporter (SLC6A4) and serotonin receptor (e.g. 5HT1A, 1B, 2A) genes have found weak, inconsistent associations with depression (Lemonde et al., 2003; Parsey et al., 2006; Huang et al., 2004; Caspi et al., 2003; Lotrich and Pollock, 2004; Surtees et al., 2006; McMahon et al., 2006). This suggests that genes outside of the serotonergic system, may also be important in the aetiology of depressive disorders such as childhood-onset mood disorder (COMD). Oxytocin (OXT) and prolactin (PRL) are neuropeptide hormones that have been 
shown to be associated with antidepressant activity, to interact with the serotonin system and to be involved in the stress response and the formation of social bonds.

Oxytocin has been proposed to balance the suppression of the serotonergic system by the hypothalamic-pituitary-adrenal axis (HPA) following stressful events (Legros, 2001) and reduce anxiety (Domes et al., 2007). Evidence from animal and human investigation supports the notion of a relationship between oxytocin and serotonin systems (Emiliano et al., 2007; Lee et al., 2003; Amico et al., 2004). Published studies suggest that stress and fear induce compensatory (Windle et al., 2004; Ebner et al., 2005; Kirsch et al., 2005) changes in OXT expression. Human biomarker studies provide another line of evidence implicating oxytocin in depressive symptoms (Zetzsche et al., 1996; Bell et al., 2006; Scantamburlo et al., 2007; Cyranowski et al., 2008; Costa et al., 2009).

Prolactin secretion is also dependent on the serotonergic system. Human serum PRL levels have been shown to reflect serotonergic function via D-fenfluramine challenge (Lee et al., 2003; Mann et al., 1995). Studies show that the prolactin response to D-fenfluramine and serotonergic agents is blunted in depressed individuals compared to controls (Mann et al., 1995; Heninger et al., 1984; Golden et al., 1992; Anderson et al., 1992; Papakostas et al., 2006). Several papers show stress-induced increases in PRL (Drago et al., 1990; Bodnár et al., 2004; Torner et al., 2004). The postpartum antidepressant-like effects of lactation may be mediated by the parity of the mother (Sibolboro Mezzacappa and Endicott, 2007). Plasma PRL levels in response to tryptophan challenge are associated with neuroticism, a correlate of depressive disorders (Brummett et al., 2008). Still other results support an OXT-PRL feedback loop in the hypothalamus (Liu and Ben-Jonathan, 1994; Kokay et al., 2006).

\subsubsection{BDNF gene}

Numerous other candidate genes have been studied as potential risk factors for COD (Rice, 2010), including the BDNF locus. BDNF Val66Met is a SNP of nucleotide 196 in exon 5, resulting in a Val/Met amino acid change in codon 66, affecting the pro-BDNF sequence, with no functional effect on the mature BDNF, but causing changes in its cellular transport and secretion. 


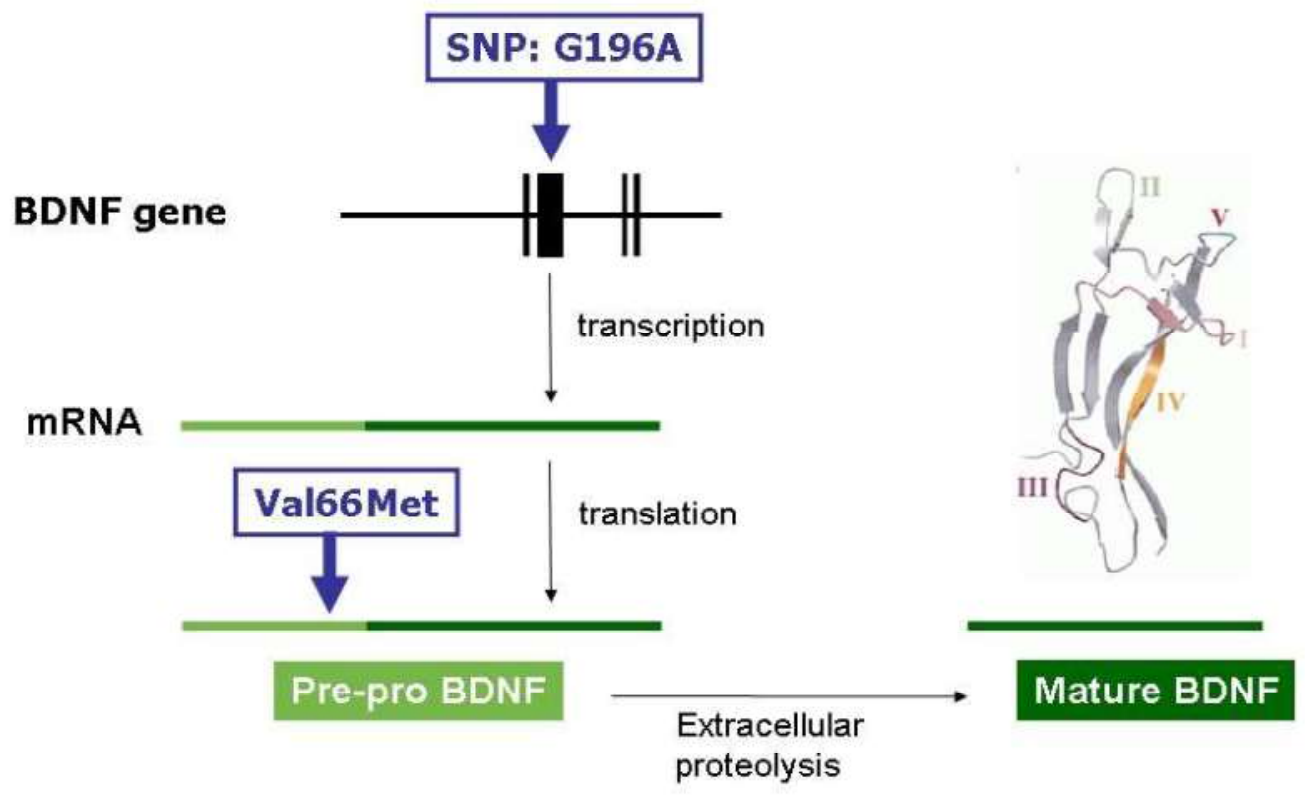

Figure 1. BDNF polymorphism

The encoded protein is a neurotrophin, playing a role in hippocampal dendritic morphology and synaptic function. It has been implicated in depression, evidenced by decreased hippocampal volume and hippocampal and serum BDNF levels associated with the disease. (Savitz and Drevets, 2009; Sen et al., 2008, Cardoner et al., 2013). The presence of the Val66Met Met allele has been associated with inefficient secretion of BDNF regardless of gender (Egan et al., 2003; Ozan et al., 2010) and decreased serum BDNF levels were found in patients with depression (Ozan et al., 2010). 


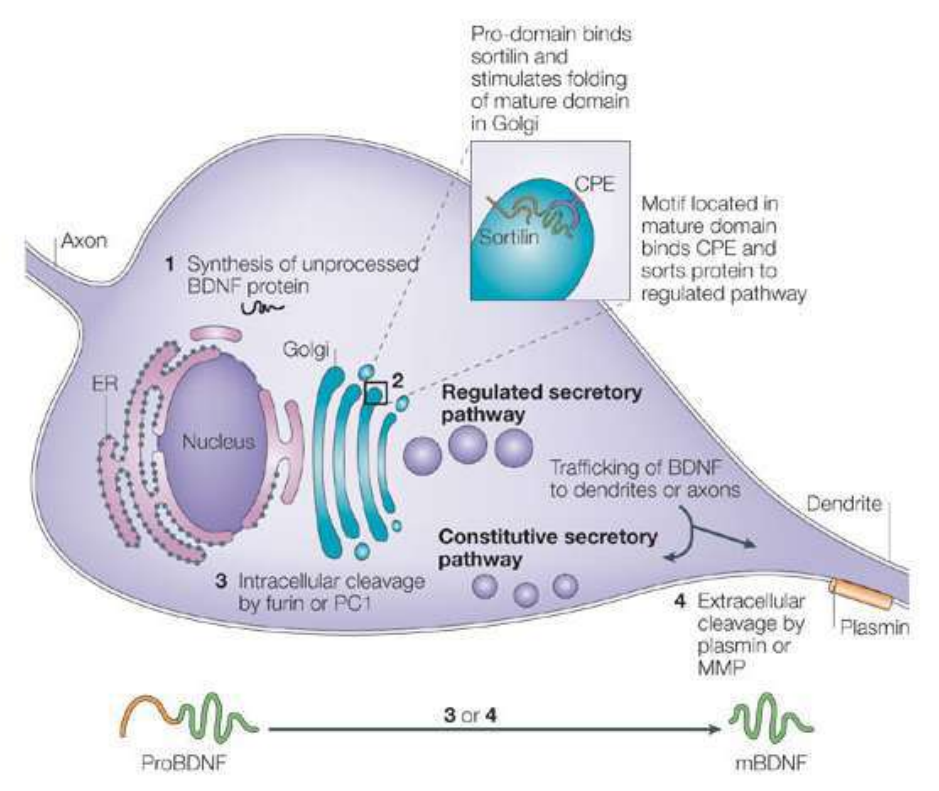

Capyright $\odot 2005$ Nature Publishing Group Nature Reviews | Neuroscience

Figure 2. Cellular transport and secretion of BDNF

In a sample of adults with a history of childhood onset mood disorder (COMD) (Strauss et al., $2004)$ the $B D N F$ Val66Met-(GT) $)_{\mathrm{n}}$ two marker Val/short ( $<170 \mathrm{bp}$ ) haplotype was associated with COMD, but no significant association was found between the examined BDNF polymorphisms and childhood-onset mood disorder by allelic or genotypic analysis. In another study, the same authors examined a sample of 258 Hungarian trios including juvenile probands with COMD and found the $B D N F$ Val66Met Val allele to be associated with the disorder (Strauss et al., 2005). Importantly, the present study is performed on a subset of the same Hungarian sample. Noteworthy, a meta-analysis of Chen et al. (2008) did not confirm the association between Val66Met polymorphism and depression. Also, in contrast to the often reported association between the $B D N F$ polymorphism and depression, the meta-analysis of Verhagen et al. (2010) suggests only a gender-dependent role of the polymorphism in the development of depression, as significant association was found only in males. 


\subsubsection{Inflammatory cytokine gene variant}

It is known that the genetic variants of inflammatory cytokines can play a role in the appearance of depression (Misener et al., 2008). In a previous study, increased interferon-gamma (IFN $\gamma$ ) level was found in a sample of adolescents with major depression (Gabbay et al., 2009). Another study showed that the increase in the level of interferon-gamma correlates with the interferongamma +874 T/A single nucleotide polymorphism (Pravica et al., 2000).

\subsection{Factors which may influence the link between genetic liability and depression}

\subsubsection{Melancholic phenotype of depression}

In this work a number of factors are considered that could contribute to and/or moderate the liability to depression. The limited success of genetic studies might arise from current classification schemas including DSM-IV, since they are based on clusters of syndromes in a heterogeneous patient group (Hasler et al., 2004). MDD as defined in DSM-IV is a heterogeneous disorder with regard to etiology, symptoms and level of functioning and response to treatment (Domschke et al., 2010).

One of the clinical subtypes of MDD that showed distinct clinical (Kessler et al., 1997b) and biochemical (Maes et al., 1990) features was melancholic depression (Gold et al. 2002). Schotte et al. (1997) provided the validation through cluster analysis of melancholic and nonmelancholic subtypes of unipolar depression.

A promising attempt has been made to determine the nosological status and diagnostic strategies to melancholia (Parker and Paterson, 2014). Furthermore, several biological markers have been suggested to identify this putative endophenotype. The preliminary results of Bracht et al., (2013) suggest that the melancholic subtype of MDD is characterized by white matter microstructure alterations of the medial forebrain bundle compared to healthy controls, while it did not differ between the healthy controls and the overall MDD sample. Though some studies claim that psychomotor retardation is a feature of depression (Widlöcher et al., 1983, Dantchev, 1998), some authors suggested that psychomotor retardation allows determining putative endophenotypes such as melancholy (Bennabi et al., 2013, Parker et al., 1996). Preliminary evidence suggests that genetic factors may discriminate melancholic and non-melancholic depression in a putatively interesting preliminary study of Quinn et al. (2012) with low sample 
size. The authors (Quinn et al., 2012) found that the BDNF rs6265 Met allele predisposes nonmelancholic depression and the interaction of the $B D N F$ rs6265 Met allele and stressful life event (SLE) predicts non-melancholia over main effects. Furthermore, in a study of Patas et al. (2014) investigating the association between serum brain-derived neurotrophic factor and plasma interleukin-6 in major depressive disorder, plasma interleukin-6 was found to be a positive predictor of BDNF only in the melancholic sample. According to Harkness et al. (2006) subjects with severe melancholic depression are more sensitive to stress, with episodes being influenced by more minor stressors than those of non-melancholic patients.

\subsubsection{Somatic type of depression}

Another putatively interesting phenotype is the somatic type of depression (STOD). Inflammatory cytokines induce behavioural symptoms, known as sickness behaviour (SB), that are similar to symptoms seen in depression (fatigue, altered sleep patterns, psychomotor retardation, social withdrawal, appetite loss, anhedonia and impaired cognitive function). INF- $\gamma$ is primarily secreted by T-lymphocytes, it usually provokes fatigue, malaise, headache, lack of appetite, weight loss, weakness, lethargy and decreased concentration, which can all be symptoms of depression (Fent et al., 1987, Triozzi et. al., 1990). This similarity led to the theory that the imbalance of inflammatory cytokines can contribute to the development of depression.

\subsubsection{Role of stressful life events}

Indeed, the role of stressful life events has been proven in depression (Kessler et al., 1997a) and several studies showed the effect of gene by environment $(\mathrm{G} \times \mathrm{E})$ interaction on mood disorders. Many environmental factors have been identified, including early and recent stressful life events (Caspi et al., 2003) and parental depression (Bouma et al., 2008), which may interact with the genetic background (Ebmeier et al., 2006). For example, the short allele of the serotonin transporter 5-HTTLPR polymorphism compared to the long allele exhibited more depression and suicidality in relation to stressful life events in a number of studies (Caspi et al., 2003, Kaufman et al., 2004, Eley et al., 2004). Although this association was not confirmed in the meta-analysis of Risch et al. (2009), it thus seems that MDD is caused by numerous interacting genetic and non-genetic factors. 
In a study of Bukh et al. (2009) the Met allele of the BDNF Val66Met polymorphism was independently associated with the presence of SLEs prior to the onset of depression and in a paper of Elzinga et al. (2011) BDNF Met allele carriers were found to be sensitive to early SLEs. Kim et al. (2007) found significant interaction of stressful life events and BDNF Met/Met and Val/Met genotypes on the risk of depression. In a study of Chen et al. (2012) on a sample of 780 pairs of ethnic Han Chinese adolescent twins, authors found that the $B D N F$ Val allele modulates the influence of environmental stress on depression. Interaction between BDNF Val66Met polymorphism and environmental stress on depression was found even when separating pure environmental factors from the environmental factors under partial genetic control and adopting a prospective longitudinal design (Chen et al., 2013). In a study of Hosang et al. (2014) the Met allele of $B D N F$ significantly moderates the relationship between life stress and depression, the association being stronger for an interaction with stressful life events and weaker for interaction of BDNF Val66Met with childhood adversity. In the study of Brown et al. (2014) the Met alleles of $B D N F$ Val66Met significantly moderated the relationship between recent life events and adult onsets of depression, though $B D N F$ did not significantly influence the effect of childhood maltreatment on chronic depression.

An illustrative example of how difficult it is to find replicable gene-MDD associations is provided by a study by Bosker and colleagues (2011). In their meta-analysis of 92 single nucleotide polymorphisms from 57 candidate genes previously reported to be significantly associated with MDD only four SNPs from four genes were found to replicate. Even these associations may turn out to be false positives due to multiple testing.

Genome wide association studies, up to date best suited for detecting variants with minor effect (Shyn et al., 2010) haven't shown genome-wide significant findings, though their non-significant top signals may be promising. Top signals may point to the possible role of synaptic processes in the genetic background of depression (Sullivan et al., 2009, Shyn et al., 2011). A number of classical pathways were associated with depression, firstly those of monoamines, from which the most commonly examined pathways are serotonergic, dopaminergic and noradrenergic pathways and the nitric oxide pathway (Smoller, 2016). 


\subsection{Aims and hypotheses}

1) We tested whether single nucleotide polymorphisms (SNPs) at the loci for $O X T, P R L$ and their receptors are associated with childhood-onset mood disorders (COMD).

Based on our preliminary studies regarding the $B D N F$ Val66Met polymorphism in depressed children and their siblings, to improve our knowledge about the potential genetic contributors to the melancholic type of depression, we examined whether an effect of the $B D N F$ Val66Met polymorphism, and interaction of the $B D N F$ Val66Met polymorphism with stressful life events could differentiate juvenile melancholic and nonmelancholic patients.

2) Specifically, we hypothesized that:

a. Melancholic and non-melancholic depressed probands are characterized by different $B D N F$ Val66Met genotype and allele distributions

b. Past exposure to stressful life events interacts with the BDNF Val66Met polymorphism to predict a melancholic depression phenotype

Furthermore, we examined the possible association between interferon-gamma $+874 \mathrm{~T} / \mathrm{A}$ single nucleotide polymorphism and the development of a symptomatically homogenous type of childhood onset depression.

3) We hypothesized that:

Depressed probands showing and those not showing the investigated group of somatic symptoms are characterized by different $I F N-\gamma+874 \mathrm{~T} / \mathrm{A}$ gene and allele distributions

These studies are innovatively integrating recent work on the molecular genetics of childhoodonset MDD. 


\section{Methods}

\subsection{Participants, enrolment and assessment procedures in the Childhood Onset Major Depression study}

In our present work we report on three different but connected studies using depressed probands and their unaffected siblings on a large sample, which is representative to the Hungarian outpatient and clinic-referred population of depressed youths as the recruitment sites supported more than approximately $85 \%$ of the newly referred cases during the study period.

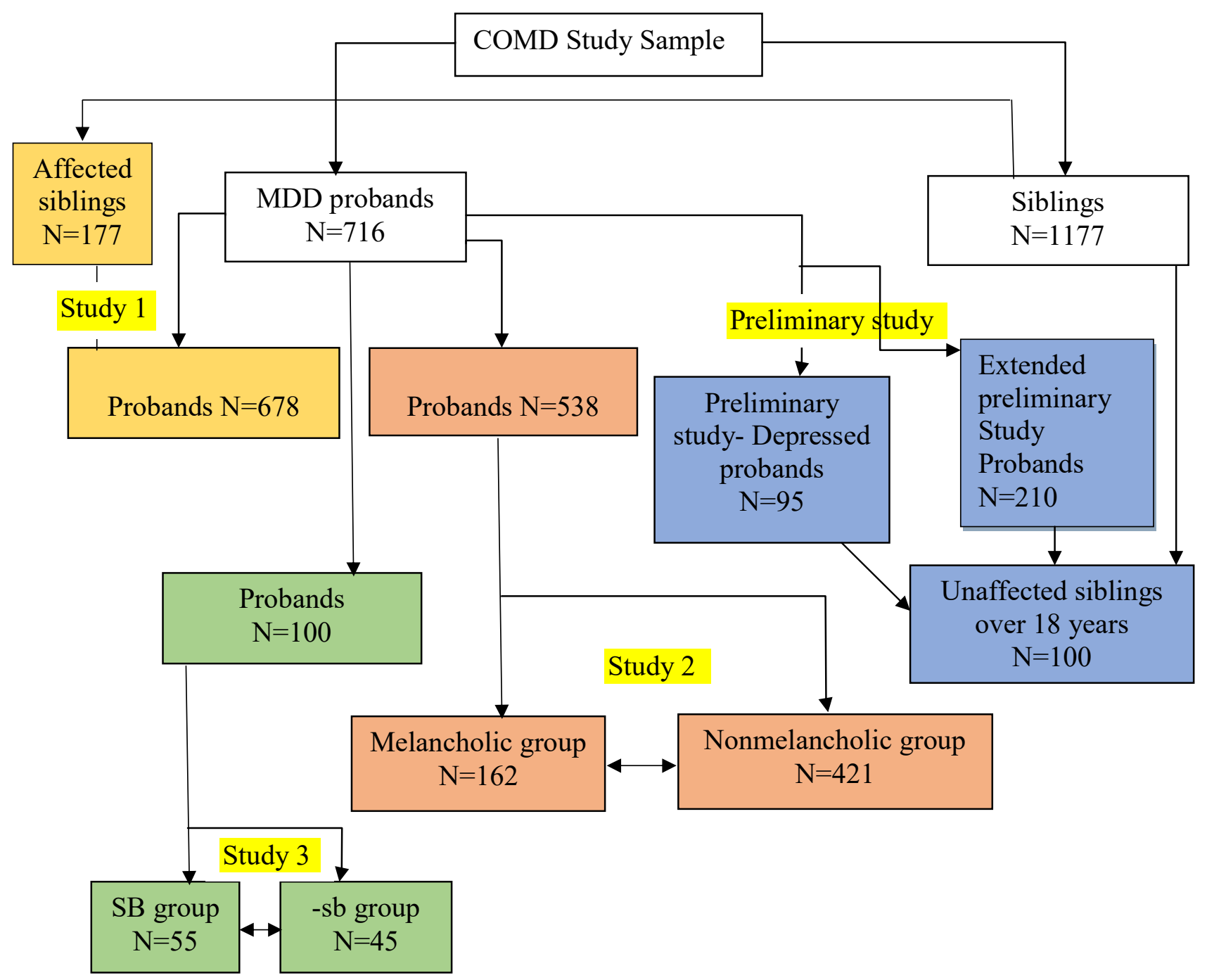

Figure 3. Description of the entire sample and the identified subgroups 
Table 1. Descriptions of the samples and hypotheses

\begin{tabular}{|c|c|c|c|}
\hline \multirow[b]{3}{*}{$\begin{array}{l}\text { Study } 1 \\
\text { (oxytocin and } \\
\text { prolactin) }\end{array}$} & \multicolumn{2}{|c|}{ Subsample } & \multirow[b]{2}{*}{ Hypotheses } \\
\hline & Group & $\begin{array}{l}\text { Comparator } \\
\text { group }\end{array}$ & \\
\hline & $\begin{array}{l}678 \text { probands } \\
\text { and } 177 \text { affected } \\
\text { siblings }\end{array}$ & o- T & $\begin{array}{l}\text { Association of OXT and PRL and } \\
\text { their receptors with COMD }\end{array}$ \\
\hline $\begin{array}{l}\text { Preliminary } \\
\text { (BDNF) }\end{array}$ & $\begin{array}{c}95 / 210 \\
\text { probands }\end{array}$ & $\begin{array}{l}100 \text { unaffected } \\
\text { siblings }\end{array}$ & $\begin{array}{l}\text { Association of BDNF Val66Met } \\
\text { with depression and melancholy }\end{array}$ \\
\hline $\begin{array}{l}\text { Study } 2 \text { (BDNF } \\
\text { X SLE) }\end{array}$ & $\begin{array}{l}162 \text { melancholic } \\
\text { probands }\end{array}$ & $\begin{array}{l}421 \text { non- } \\
\text { melancholic } \\
\text { probands }\end{array}$ & $\begin{array}{l}\text { Association of BDNF Val66Met } \\
\text { with melancholy and role of } \\
\text { interaction with SLE }\end{array}$ \\
\hline $\begin{array}{c}\text { Study } 3 \\
(\text { IFN } \gamma+874)\end{array}$ & $\begin{array}{c}55 \text { probands } \\
\text { showing somatic } \\
\text { symptoms }\end{array}$ & $\begin{array}{l}45 \text { probands } \\
\text { without somatic } \\
\text { symptoms }\end{array}$ & $\begin{array}{l}\text { Association of IFN } \gamma+874 \text { with } \\
\text { somatic symptoms }\end{array}$ \\
\hline
\end{tabular}

The data derive from a multidisciplinary Program Project studying genetic and psychosocial risk factors for COMD. The project was conducted in Hungary, in collaboration with Pittsburgh University, NIMH grant \#MH056193. The sample includes in total 716 depressed probands, recruited from 23 mental health facilities across the country, including 7 child and adolescent psychiatry inpatient units. Screening of probands was performed from 01.11.1999 to 01.07.2005. Signed consent from the parents and assent from the children were obtained from all subjects in accordance with the Hungarian National Health and the Regional Human Investigation Review Board guidelines, in accordance with the legal requirements in Hungary and the University of Pittsburgh, Pittsburgh, USA. Table 1 and figure 3 describes the entire sample and shows the identified subgroups. Inclusion criteria were the following: DSM-IV diagnosis of MDD with the onset of the first episode from 7.0 years by age 14.9 and being free of mental retardation and major systemic medical disorders, with at least one biologic parent and a $7-17.9$-year-old sibling available. At first, children were selected on the basis of a depressive symptom screen, the short version of the Children's Depression Inventory (Kovacs et al., 2003), having to reach the cut-off score for inclusion. The instrument was selected during the course of a pilot study to maximize sensitivity and specificity. Screen cut-off and also screening measure used were adjusted during the recruitment phase in order to minimize false positives. The diagnostic procedure included an 
audiotaped semi-structured Interview Schedule for Children and Adolescents - Diagnostic Version (ISCA-D), an extension of the Interview Schedule for Children and Adolescents (ISCA) (Sherrill et al., 2000). The interviewers were child- and adolescent psychiatrists and psychologists, who completed 3 months of didactic and practical training in the interview technique (an average of $85 \%$ symptom-agreement reached on 5 consecutive videotaped interviews against "gold standard" interview ratings provided by the trainers). Interrater reliability on ISCA-D symptoms was satisfactory.

Ratings were obtained both for current and past symptoms of DSM-IV Axis I diagnoses and major DSM-III disorders (e.g. depression with melancholic features). The evaluation consisted of 2 different parts, conducted by different clinicians, approximately 6 weeks apart. The diagnostic assessment for the participants enrolled in this study has been described further in detail previously (Kapornai et al., 2007; Kiss et al., 2007; Liu et al., 2006). Importantly, to establish depressive episodes and symptoms, we performed two independent semi-structured diagnostic interviews during the intake procedure rated by trained clinicians, and subsequently evaluated by Best-Estimate Diagnostic Procedure (Maziade et al., 1992). The "Mood Disorder Module" of the semi-structured diagnostic interview was administered first, together with the Intake General Information Sheet (IGIS). A time-line with named anchors was created during the interview, in order to identify present and past depressive episodes (with onset and offset dates as punctual as possible) and to document the occurrence of any of a range of significant life events. The anchors consisted of both general and personal events.

If the child had met DSM criteria for mood disorder at the first evaluation, the full semistructured diagnostic interview and a completion with additional self-rated scales were administered. Not only the child was interviewed about him/herself, but also the parent about the child. Pairs of senior child psychiatrists, trained as Best Estimate Diagnosticians (BEDs), separately reviewed all material, and then together derived consensus diagnoses and decided whether the child entered the "Proband" status. 


\subsubsection{Study 1. Investigating the oxytocin or prolactin gene variants}

In the investigation of oxytocin or prolactin gene variants, we included 678 families (Figure 3) with at least one biological parent and a proband in the statistical analyses. In Study 1, there were 855 affected participants - probands $(n=678)$ and affected siblings $(n=177)$ met DSM-IV criteria for either unipolar depression $(n=838)$ prior to age 14 years or bipolar disorder $(n=17)$ prior to age 17 years. The mean proband age at study entry was 12.6 years [S.D. 2.32 years]. Probands were 55\% male. Bipolar cases were included in the analyses since a significant proportion of unipolar children will switch as they mature (Kovacs et al., 1997; Geller et al., 2001) - less than $1 \%$ of the entire sample had a bipolar spectrum diagnosis at intake (Dempster et al., 2007) -, and evidence that unipolar and bipolar illnesses share inherited risk (McGuffin et al., 2003).

\subsubsection{Preliminary studies testing the $B D N F$ Val66Met polymorphism in depressed children and their unaffected siblings}

The aim of our preliminary study on the $B D N F$ Val66Met polymorphism was to examine the relationship between the polymorphism and childhood-onset depression, additionally, melancholy as an alternative phenotype, the somato-vegetative symptoms as phenotypic characteristics and stress related life events as environmental factors. Ninety-five depressive patients and their 100 healthy siblings without psychiatric history above 18 years of age were involved in this study. Probands were $50,5 \%$ and siblings were $48 \%$ male. The average age of the probands from this first sample was $11,35 \pm 1,8$ years and that of the siblings was $18,4 \pm 1,3$ years. Depressive episodes and symptoms were examined with semi-structured interview (ISCAD). Melancholic phenotype was separated on the basis of the additional question of ISCA-D referring to the different quality of depressed mood.

Extending our analysis, we compared 210 depressed (Figure 3) probands and their 100 unaffected siblings. Therefore, our largest case number regarding the preliminary studies is 210 . Screening of probands was performed from 01.11.1999. to 01.07.2005, and siblings from 01.11.1999 to 31.05.2008. Distribution of probands by gender and age was 116 males $(55.2 \%)$, mean age: $13.08 \pm 2.3$ years. 
In this study we defined subgroups within depression according to the presence of melancholic symptom on the basis of an item of the diagnostic interview referring to the distinct quality of depressed mood. (This feeling of sadness since ... is/was this different than the feeling you get when a friend moves away? Is/was this like a 'missing feeling' or a 'lonely feeling? How is it different? Is it like being in a dark cave? Has anyone close to you died? A pet? Can you remember how you felt then? How is/was your feeling now? Did you feel any different? In what way...?). Ratings were obtained for both current and past symptoms. The distribution of melancholic and non-melancholic phenotypes between the depressed group was the following: 24 (11.4\%) participants currently melancholic, 16 (7.7\%) with a past melancholic depressive episode and 4 (1.9\%) both current and past melancholy.

Siblings of child probands were subjected to the same research screening procedure and in case of positive screening, to the same comprehensive diagnostic assessment procedure, detailed above. Both probands and siblings were followed up by a yearly mail-follow-up test package (MFU), including: a) parental report of interim medical and psychosocial events (short version of our IGIS $=$ SR-GIS) and a 26-item DSM depressive symptom checklist (DSC) and b) each child's self-rated depression scale (short CDI). In case of positive screening, a diagnostic assessment procedure followed. All the siblings who haven't screened positive on the follow-up package before 18 years of age, were invited for assessment. 100 siblings over 18 years of age were involved in the study as controls (48 males (48\%), mean age: 18,04 $\pm 1,3$ years), whose assessment procedure excluded the existence of current as well as lifetime episode of major depression or any other major psychiatric morbidity.

\subsubsection{Study 2. Investigating the melancholic and the nonmelancholic depressed groups}

Studying the $B D N F$ Val66MET polymorphism on an even larger sample, the depressed group was divided into two groups on the basis of an improved classification method investigating the presence of the melancholic subtype. From the COMD study sample 583 depressed probands were included in Study 2 (Figure 3). Melancholic subtype of depression was estimated by ISCA$\mathrm{D}$, on the basis of the criteria for melancholic features of the DSM-IV. The differentiating symptoms were pervasive, nonreactive anhedonia, distinct quality of depressed mood, depression worse in the morning, early morning awakening, marked psychomotor retardation or agitation, 
anorexia, weight loss and excessive and inappropriate guilt. 135 subjects met criteria for melancholic depression in the current time-frame, and 44 subjects had such features during a past episode. There were overlaps between the two groups given that some subjects had melancholy in both time frames. Thus, 162 subjects met criteria for melancholic depression in at least one time frame. The mean age of depressed subjects at first interview was $11.72(\mathrm{SD}=2.01)$ years. The melancholic group $(\mathrm{N}=162)$ had a mean age of $11.71(\mathrm{SD}=2.01)$ and the non-melancholic group $(\mathrm{N}=421)$ had a mean age of $11.76(\mathrm{SD}=2.01)$. The distribution by gender was $55.6 \%$ male $(n=324)$ in the total depressed group, $46.9 \%$ male $(n=76)$ in the melancholic group and $58.9 \%$ male ( $\mathrm{n}=248)$ in the non-melancholic group (see Table 2 for further details).

Table 2. Characteristics of the total depressed group and the melancholic and nonmelancholic patients

\begin{tabular}{llll} 
& Depressed group $2(\mathrm{n}=583)$ & MEL $(\mathrm{n}=162)$ & NMEL $(\mathrm{n}=421)$ \\
\hline Age of onset (years) & $11.7 \pm 2.0$ & $11.7 \pm 2.0$ & $11.7 \pm 2.0$ \\
Male/female & $324 / 259$ & $76 / 86$ & $248 / 173$ \\
SLE (mean \pm SD) & $6.07 \pm 2.86$ & $5.84 \pm 3.03$ & $6.15 \pm 2.78$ \\
\hline
\end{tabular}

MEL, melancholic; NMEL, nonmelancholic; SLE, stressful life event.

Life events were abstracted from a pre-coded demographic data sheet, the Intake General Information Sheet (IGIS), completed by clinicians as part of the intake psychiatric interview, using parents as informants. On the basis of the study of Mayer et al. (2009), 22 of the 26 stressful life events were separated into five clinically meaningful groups: "Parental health", "Death of close relatives", "Sociodemographic" and "Intrafamilial". Miscellaneous events formed the fifth group containing items reflecting extrafamilial life events and abuse. A continuous weighted total score reflecting the number of stressful life events was also computed from the 26 items. Both the total and the grouped scores of stressful life event items were weighted by age (age in years at the intake ISCA-D interview)

\subsubsection{Study 3. Investigating the interferon-gamma $+874 \mathrm{~T} / \mathrm{A}$ polymorphism}

100 Hungarian patients with childhood onset depression were involved in this study (55 probands in the sickness behaviour (SB) group and 45 probands in the comparison group) (Figure 3). Diagnostic procedure included the above detailed Interview Schedule for Children and Adolescents - Diagnostic Version, a semi- structured interview, based on DSM-IV. Covering 
the subject's current episode and lifespan, we examined six somatic symptoms that characterize sickness behaviour (SB) and depression, too (fatigue, altered sleep patterns, psychomotor retardation, appetite loss, anhedonia and impaired cognitive function).

We did not examine social withdrawal, as it is not listed in the diagnostic symptoms of major depressive disorder (according to DSM-IV).

In the presence of at least five of the somatic symptoms, that were frequent, considerable, and noticeable and interfered with functioning, we categorized the subject into the SB group. We compared this SB group with those depressed subjects who did not fulfil these criteria (-sb: comparison group) (Table 3 ).

Table 3. Characteristics of the subgroups

\begin{tabular}{ccccc} 
Depressed group 3 & Male (\%) & Female (\%) & Total & Average age (year) \\
\hline SB group & $30(54 \%)$ & $25(46 \%)$ & 55 & $13.25 \pm 4.09$ \\
-sb group & $25(55 \%)$ & $20(45 \%)$ & 45 & $13.68 \pm 5.17$ \\
\hline
\end{tabular}

\subsection{Diagnostic tools and questionnaires}

\subsubsection{Intake General Information Sheet for Children and Adolescents (IGIS)}

The IGIS is a fully structured interview containing pre-coded item response choices. In the IGIS the parent is interviewed about the child's socio-demographic/family background, developmental, educational, and health history, and major life events at the intake in the investigation.

\subsubsection{Interview Schedule for Children and Adolescents - Diagnostic Version Present and Lifetime (ISCA-D-PL)}

Major depression was diagnosed using the ISCA-D-PL semi-structured psychiatric interview, assessing both lifetime and current disorders in children and youths (Sherrill \& Kovacs, 2000). Furthermore, it includes most DSM-IV Axis-I diagnoses and even some DSM-III symptoms. The clinicians rating is based on both the parent informants and the child's/youth's answer, by deriving a final rating for each symptom. Although the ISCA-D is designed to 
provide information even on depression severity, this feature has not been used in the present studies.

Melancholic subtype of depression was estimated by ISCA-D-PL, in case of having the DSM-IV diagnosis of major depression, on the basis of the additional criteria for melancholic features of the DSM-IV: Either of the following, occurring during the most severe period of the current episode:

(1) loss of pleasure in all, or almost all activities

(2) lack of reactivity to usually pleasurable stimuli

Three (or more) of the following:

(1) distinct quality of depressed mood

(2) depression regularly worse in the morning

(3) early morning awakening (at least two hours before usual time before the awakening)

(4) marked psychomotor retardation or agitation

(5) significant anorexia or weight loss

(6) excessive or inappropriate guilt.

\subsubsection{Children Depression Inventory-Short Version (CDI-Short Form)}

As a part of the initial assessment, the 10-item CDI Short Form was developed. The CDI in its original form is a 27-item self-rated questionnaire for children and adolescents. The Short Form is a multi-rater assessment of depressive symptoms in youth aged 7 to 17 years correlating with the full inventory $(\mathrm{r}=0,89)$, administered and scored using paper-and-pencil format in the present study, providing streamline evaluation of depressive symptoms. Each item consists of three choices, keyed 0 (absence of a symptom), 1 (mild symptom), 2 (definite symptom), with higher scores indicating increasing severity. The total score can range from 0 to 20 . The cut-off value for clinical depression is 7 points (Mayer et al., 2006). 


\subsection{Statistical analyses and laboratory methods}

\subsubsection{Statistical analyses}

To study oxytocin and prolactin gene variants, several analyses were performed using Haploview v 3.32 (Barrett et al., 2005), including Hardy-Weinberg equilibrium and Mendelian inheritance, and the transmission disequilibrium test (TDT). A corrected significance threshold was calculated for each gene using Nyholt's (2004) spectral decomposition (SNPSpD) method. Correction by SNPSpD was followed by correction for the number of genes tested, to account for multiple comparisons. Haplotype blocks were defined using the Gabriel et al. (2002) criteria. All haplotypes with a frequency greater than 0.05 were also tested for association with COMD.

To compare melancholic depressed participants to the non-melancholic depressed ones, to compare melancholic depressed participants to their unaffected siblings (with no detectable Axis I DSM-IV disorder) and to compare probands with and without the somatic type of depression, we applied the following statistical methods:

Data analysis was carried out using the software package SPSS Statistics, version 17 (SPSS Inc., Chicago, Illinois, USA). Group characteristics were investigated using an independent-samples ttest and the $\chi^{2}$-test. Fisher's exact test was used to compare allele frequencies and the $\chi^{2}$ - test of statistical significance set at $p$ less than 0.05 was used to compare genotype frequencies among the non-melancholic and melancholic subgroups, furthermore among melancholic probands and their unaffected siblings. Logistic regression models were performed to examine the total weighted and grouped weighted life event scores and BDNF Val66Met genotypes. We used these models in the total melancholic group. Main effects and possible interactions were tested using the likelihood ratio test (stepwise regression). In the first model (Model 1), the main effects of the total weighted life event score and Val66Met genotypes were tested. Second, we included the interaction term of total weighted life event scores and Val66Met genotypes. In the second model (Model 2), the genotype and the main effects of grouped life events scores were tested, later adding the interaction terms between grouped life event scores and Val66Met genotypes. The main effects of SLEs were analysed continuously as continuous score yields more information than dichotomous variables, yielding more sensitive results. Effect size was counted for the genotype-by-melancholia interaction and power analysis was carried out using GPower 
(Faul et al., 2007). For the power calculation of the logistic regression analysis, the POWER procedure in SAS 9.4 was used.

\subsubsection{Laboratory methods}

To genotype single nucleotide polymorphisms across the $O X T$ and $P R L$ genes and their receptors, genomic DNA was isolated from blood for each participant using a high-salt method (Lahiri and Nurnberger, 1991). Four buccal swabs were also collected per individual for quality control purposes including resolution or confirmation of Mendelian inconsistencies. SNPs were selected for each of the four genes based on Caucasian linkage disequilibrium (LD) plots from the International HapMap project database (www.hapmap.org) with a minimum minor allele frequency (MAF) of 20\% (Table 4). SNPs were genotyped independently using 50 ng DNA in a standard Applied Biosystems (Foster City, CA) TaqMan ${ }^{\circledR}$ assay-on-demand reaction modified for a $10 \mu \mathrm{l}$ final volume. Amplified products were analysed on an AB 7500 Sequence Detection System. 
Table 4. Oxytocin and prolactin system genetic marker information

\begin{tabular}{|c|c|c|c|c|c|c|c|c|}
\hline Gene & SNP & Chromosome & Position & $\begin{array}{c}\text { Observed } \\
\text { heterozygosity }\end{array}$ & $\begin{array}{c}\text { HWE } \\
p- \\
\text { value }\end{array}$ & $\begin{array}{c}\% \\
\text { Genotyped }\end{array}$ & $\begin{array}{l}\text { Minor } \\
\text { allele }\end{array}$ & $\begin{array}{c}\text { Minor } \\
\text { allele } \\
\text { frequency }\end{array}$ \\
\hline \multirow[t]{3}{*}{$O X T$} & rs2740210 & $20 \mathrm{p} 13$ & 3001255 & 0.43 & 0.31 & 98 & $\mathrm{~A}$ & 0.34 \\
\hline & rs2770378 & $20 \mathrm{p} 13$ & 3001514 & 0.48 & 0.50 & 97 & A & 0.42 \\
\hline & rs4813627 & $20 \mathrm{p} 13$ & 3003513 & 0.49 & 0.55 & 98 & G & 0.47 \\
\hline \multirow[t]{3}{*}{$O X T R$} & rs237885 & $3 p 25$ & 8770543 & 0.49 & 0.11 & 100 & $\mathrm{~T}$ & 0.44 \\
\hline & rs2268493 & $3 \mathrm{p} 25$ & 8775840 & 0.43 & 0.32 & 96 & $\mathrm{C}$ & 0.32 \\
\hline & rs237898 & $3 \mathrm{p} 25$ & 8783495 & 0.49 & 0.37 & 100 & $\mathrm{~T}$ & 0.39 \\
\hline \multirow[t]{4}{*}{$P R L$} & rs1205961 & $6 \mathrm{p} 22.3$ & 22393991 & 0.45 & 1.00 & 100 & A & 0.35 \\
\hline & rs1205960 & $6 \mathrm{p} 22.3$ & 22396139 & 0.37 & 0.46 & 95 & $\mathrm{~T}$ & 0.25 \\
\hline & rs849886 & $6 \mathrm{p} 22.3$ & 22399346 & 0.48 & 0.62 & 100 & $\mathrm{~T}$ & 0.47 \\
\hline & rs1341239 & $6 \mathrm{p} 22.3$ & 22412183 & 0.47 & 0.78 & 100 & A & 0.39 \\
\hline \multirow[t]{6}{*}{$P R L R$} & rs 187490 & $5 \mathrm{p} 13.2$ & 35080884 & 0.41 & 0.21 & 100 & $\mathrm{C}$ & 0.31 \\
\hline & rs249522 & $5 \mathrm{p} 13.2$ & 35096076 & 0.22 & 0.87 & 98 & $\mathrm{~T}$ & 0.13 \\
\hline & rs35614689 & $5 \mathrm{p} 13.2$ & 35134877 & 0.51 & 0.71 & 95 & G & 0.48 \\
\hline & rs4703505 & $5 \mathrm{p} 13.2$ & 35207778 & 0.40 & 0.74 & 92 & A & 0.27 \\
\hline & rs2047740 & $5 \mathrm{p} 13.2$ & 35239149 & 0.43 & 0.30 & 100 & $\mathrm{C}$ & 0.33 \\
\hline & rs7727306 & $5 \mathrm{p} 13.2$ & 35273617 & 0.48 & 0.45 & 100 & A & 0.40 \\
\hline
\end{tabular}

In our preliminary studies on the $B D N F$ rs6265 single nucleotide polymorphism, DNA was isolated from peripheral blood leukocytes and/or buccal swab. Genetic analysis: PCR, PmaCI restriction enzyme digestion, followed by polyacrylamide gel electrophoresis with ethidium bromide staining (Tsai et al., 2003). Statistical analysis was performed using SPSS software.

On the sample of depressed probands in Study 2, the BDNF rs6265 single nucleotide polymorphism, also known as Val66Met, was genotyped using the Applied Biosystems TaqMan pre-designed assay C_11592758_10 (Applied Biosystems, Foster City, California, USA). For 
each reaction, $20 \mathrm{ng}$ genomic DNA was amplified as per the manufacturer's directions in a total volume of $10 \mu \mathrm{l}$ in an MJ Research thermocycler (Bio-Rad Laboratories, Hercules, California, USA). Each genotyping plate was analysed after amplification on the ABI Prism 7000 AQ5 Sequence Detection System (software v1.2.3) using the allelic discrimination option. Allele calls were made manually.

Genotyping of the $I F N \gamma+874 \mathrm{~T} / \mathrm{A}$ single nucleotide polymorphism has been carried out by allele specific PCR amplifications, followed by polyacrilamide gel electrophoresis and visualized by ethidium bromide (DNA was isolated from blood sample or buccal swab). After migration of the samples in the electrophoresis gel, a photo of the resulting pattern was taken (Figure 4).

\section{$\begin{array}{llllllllllllllll}M & A & B & C & D & E & F & M\end{array}$}

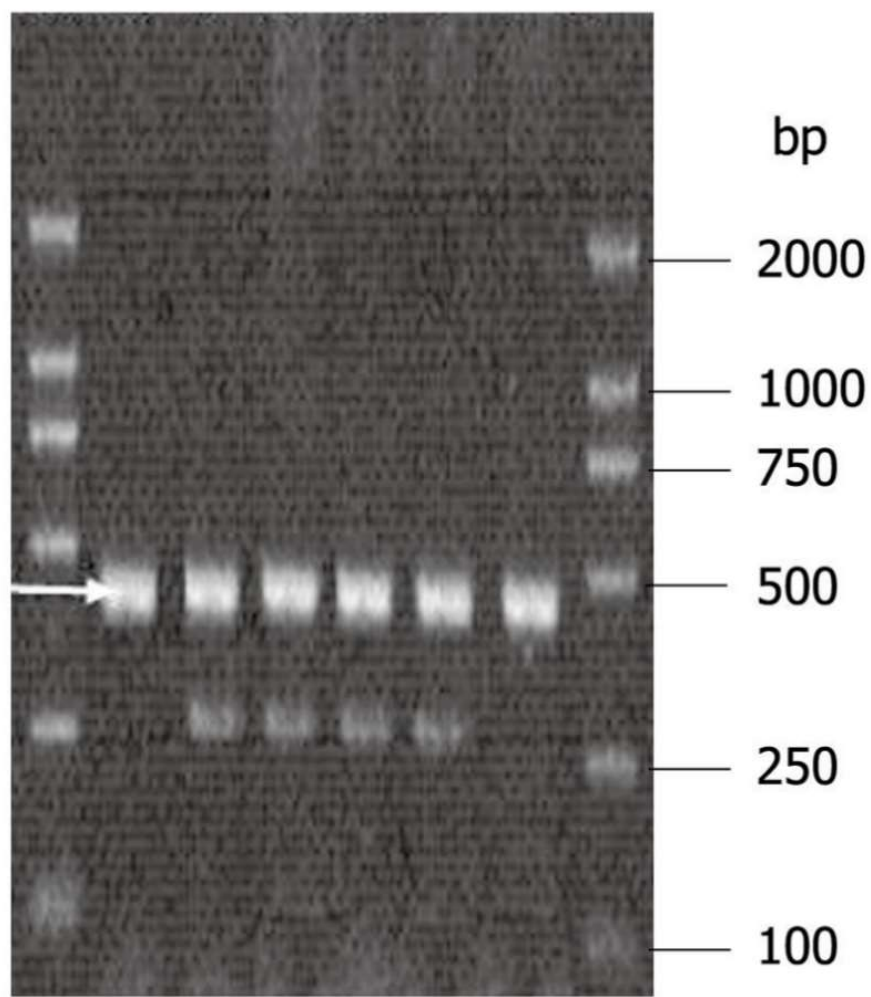

Figure 4. Representative gel picture of IFN-r +874 T/A polymorphism. M, Marker; Lane A \& B: AA (low producer) genotype; Lane C \& D: AT (medium producer) genotype; Lane E \& F: TT (high producer) 


\section{Results}

\subsection{Investigating the $O X T, O X T R, P R L$, and $P R L R$ genes in child and youth depression}

A total of 678 families were genotyped for 16 SNPs across the $O X T$, OXTR, PRL, and PRLR genes. All SNPs were in Hardy-Weinberg equilibrium $(p \geq 0.11)$. Seventeen families showed Mendelian errors. In 11 of these, inconsistencies were not due to sample handling errors, according to evaluation of buccal swabs taken from the same individual as the blood sample; these families were suspected of nongenetic familial relationships and removed from the analysis. The remaining six families with Mendelian errors showed a discrepancy between the blood and buccal swab samples for one member of the family. In the latter cases, the swab sample was used to genotype the discrepant individual. DNA from blood was used to regenotype $5 \%$ of the samples at each marker: error rates were $<1 \%$ and were explained by labelling/transcriptional errors.

Two of the three SNPs of the OXT gene, showed significant results (rs2740210: allele C overtransmitted, $\chi^{2}=5.32, p=0.02$; rs4813627: allele G overtransmitted, $\chi^{2}=6.01, p=0.01$; see Table 4). After using SNPSpD, both were nominally significant $\left(\mathrm{M}_{\mathrm{eff}}=2.35\right.$, adjusted $\alpha=$ 0.021), but they were not significant after further Bonferroni correction by the number of genes tested (adjusted $\alpha=0.005$ ). No significant associations were found for any SNPs in the OXTR, $P R L$, or PRLR genes ( $p>0.15$ (Table 5). Only one haplotype block, spanning rs1205960 and rs849886 in the $P R L$ gene, was identified. None of the haplotypes were significant. 
Table 5. Transmission disequilibrium test results for $O X T, O X T R, P R L$ and $P R L R$ markers

\begin{tabular}{|c|c|c|c|c|c|}
\hline Gene & SNP & $\begin{array}{c}\text { Overtransmitted } \\
\text { allele }\end{array}$ & Tr:Un & $x 2$ & $p$ \\
\hline \multirow[t]{3}{*}{$O X T$} & rs2740210 & $\mathrm{C}$ & $260: 210$ & 5.32 & $0.02^{1}$ \\
\hline & rs 2770378 & G & $271: 238$ & 2.14 & 0.14 \\
\hline & rs4813627 & G & $299: 242$ & 6.01 & $0.01^{1}$ \\
\hline \multirow[t]{3}{*}{ OXTR } & rs237898 & A & $278: 269$ & 0.15 & 0.70 \\
\hline & rs2268493 & A & $229: 220$ & 0.18 & 0.67 \\
\hline & rs237885 & A & $270: 263$ & 0.09 & 0.76 \\
\hline \multirow[t]{4}{*}{$P R L$} & rs 1341239 & $\mathrm{~T}$ & $277: 246$ & 1.84 & 0.18 \\
\hline & rs849886 & $\mathrm{G}$ & $297: 268$ & 1.49 & 0.22 \\
\hline & rs1205960 & G & 198:193 & 0.06 & 0.80 \\
\hline & rs1205961 & $\mathrm{T}$ & $268: 229$ & 3.06 & 0.08 \\
\hline \multirow[t]{6}{*}{$P R L R$} & rs7727306 & A & $282: 279$ & 0.02 & 0.90 \\
\hline & rs2047740 & $\mathrm{C}$ & $259: 225$ & 2.39 & 0.12 \\
\hline & rs4703505 & $\mathrm{T}$ & $184: 162$ & 1.40 & 0.24 \\
\hline & rs35614689 & $\mathrm{T}$ & $272: 253$ & 0.69 & 0.41 \\
\hline & rs249522 & G & $136: 121$ & 0.88 & 0.35 \\
\hline & rs 187490 & $\mathrm{~T}$ & $242: 230$ & 0.31 & 0.58 \\
\hline
\end{tabular}

Tr: transmitted; Un: untransmitted.

${ }^{1}$ Not significant at adjusted $\alpha=0.005$.

We performed two additional exploratory analyses to examine parent-of-origin effects (POEs) and proband sex effects for the three SNPs downstream of the $O X T$ gene, using the default TDTPHASE sub-option settings of UNPHASED v2.403 (Dudbridge, 2003), followed by a onetailed Fisher's Exact text, based on the hypothesis that oestrogen influences on OXT expression would be more relevant in transmissions to and from females. Three OXT SNPs revealed biased maternal transmissions of rs2740210 (allele A undertransmitted, relative risk $(\mathrm{RR})=0.68, \mathrm{CI}=0.46-1.03$, likelihood ratio score $(\mathrm{LRS})=7.14, p=0.007)$ and $\mathrm{rs} 4813627$ (allele A undertransmitted, $\mathrm{RR}=0.71, \mathrm{CI}=0.49-1.04, \mathrm{LRS}=6.09, p=0.01$ ), while paternal transmissions were not significant; most of the paternal transmissions were in the same direction 
as the maternal transmissions, with no parent-of-origin effect by Fisher's Exact Test ( $p$ 's $\geq 0.12$ ). Similarly, all three $O X T$ SNPs showed biased transmission to daughters, but proband sex effects were not significant after correction for multiple tests (adjusted $\alpha=0.017$ ) for rs2740210 (FET, $p$ $=0.04)$ or $\operatorname{rs} 2770378(\mathrm{FET}, p=0.02)($ Table 6$)$.

Table 6. OXT SNP transmissions according to the sex of the parent and proband

FET (one-

tailed)

\begin{tabular}{cccccccccccc}
\multirow{2}{*}{ SNP } & \multicolumn{4}{c}{ Paternal transmissions } & \multicolumn{5}{c}{ Maternal transmissions } & \multirow{2}{*}{ tailed) } \\
\cline { 2 - 9 } & Tr & Un & RR & LRS & $p$ & Tr & Un & RR & LRS & $p$ & \\
\hline rs2740210 & 108 & 95 & 0.88 & 0.83 & 0.36 & 115 & 78 & 0.68 & 7.14 & 0.007 & 0.12 \\
rs2770378 & 104 & 100 & 0.96 & 0.08 & 0.78 & 115 & 90 & 0.78 & 3.06 & 0.08 & 0.17 \\
rs4813627 & 111 & 88 & 0.79 & 2.66 & 0.1 & 125 & 89 & 0.71 & 6.09 & 0.01 & 0.32
\end{tabular}

\begin{tabular}{|c|c|c|c|c|c|c|c|c|c|c|c|}
\hline \multirow[t]{2}{*}{ SNP } & \multicolumn{5}{|c|}{ Transmissions to male probands } & \multicolumn{5}{|c|}{ Transmissions to female probands } & \multirow[t]{2}{*}{$\begin{array}{c}\text { FET (one- } \\
\text { tailed) }\end{array}$} \\
\hline & $\mathrm{Tr}$ & Un & RR & LRS & $p$ & $\operatorname{Tr}$ & Un & RR & LRS & $p$ & \\
\hline rs2740210 & 135 & 128 & 0.95 & 0.19 & 0.66 & 133 & 90 & 0.68 & 8.34 & 0.004 & 0.04 \\
\hline rs2770378 & 145 & 152 & 1.05 & 0.16 & 0.68 & 132 & 96 & 0.73 & 5.71 & 0.02 & 0.02 \\
\hline rs4813627 & 170 & 151 & 0.89 & 1.12 & 0.29 & 138 & 98 & 0.71 & 6.81 & 0.01 & 0.11 \\
\hline
\end{tabular}

Tr: transmitted; Un: untransmitted; RR: relative risk; LRS: likelihood ratio test statistic; FET: Fisher's Exact test, one-tailed $p$-value (adjusted $\alpha=0.017$ ). 


\subsection{The preliminary studies investigating the role of $B D N F$ Val66Met polymorphism in childhood onset depression}

We did not find significant difference in the frequency of $B D N F$ genotypes $(p=0.511)$ and alleles (Figure 5 and 6 ) between the depressed and the healthy sibling control groups.

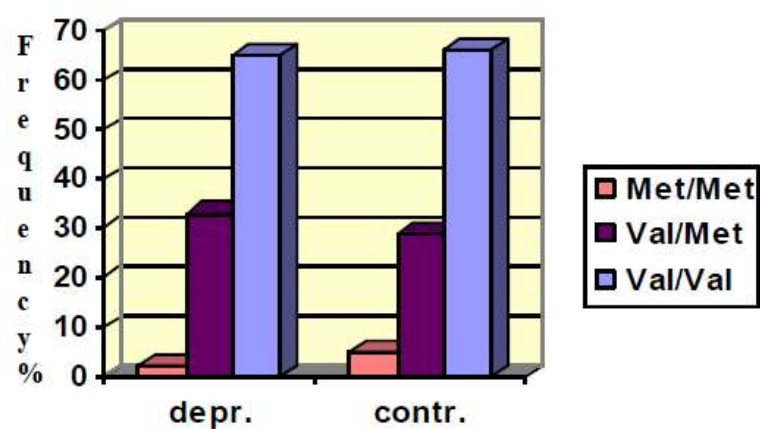

Figure 5. BDNF Val66Met genotype distribution between depressed children and their healthy siblings as controls

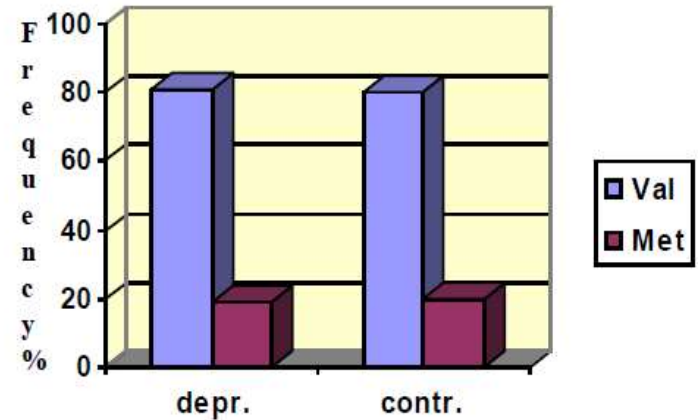

Figure 6. BDNF Val66Met allele distribution between depressed children and their healthy siblings as controls

Regarding the melancholic phenotype, $B D N F$ Val66Val genotype had a significantly higher frequency in the depressed group than in the unaffected siblings $(p=0.024)$.

We did not find significant difference in the frequency of $B D N F$ alleles between the melancholic and the non-melancholic group.

From the investigated somato-vegetative symptoms (poor concentration, memory or attention, insomnia, hypersomnia, weight loss or weight gain, psychomotor retardation or agitation) hypersomnia showed association with the frequency of Val66Met genotype $(p<0.1)$. Regarding the categorized life event groups the occurrence of psychiatric disease of family members showed association with $B D N F$ Val allele. 
In the extended preliminary study, the melancholic subgroup of depressed probands did not show significantly higher $\mathrm{Val} / \mathrm{Val}$ frequency than the unaffected control group $(p=0.28$ and 0.37 , respectively). The Val allele was not associated with the occurrence of melancholic subtype in depressive probands ( $p=0.12$ and 0.29 ) (see the Table 7 below).

Table 7. Genotype and allele distributions in melancholic probands and their unaffected siblings

Unaffected $(n=100) \quad$ Melancholic subtype $(n=24) \quad$ Melancholic subtype $(n=16)$

\begin{tabular}{|c|c|c|c|}
\hline & & Current & Past \\
\hline Genotype* & & & $* * *$ \\
\hline Met/Met & $5(5 \%)$ & $1(4.2 \%)$ & - \\
\hline Val/Met & $29(29 \%)$ & $11(45.8 \%)$ & $7(43.8 \%)$ \\
\hline Val/Val & $66(66 \%)$ & $12(50 \%)$ & $9(56.2 \%)$ \\
\hline Allele** & & & $* * * *$ \\
\hline Val & 95 & 23 & 16 \\
\hline Met & 34 & 12 & 7 \\
\hline \multicolumn{4}{|c|}{$*$ melancholic current vs. unaffected $\chi^{2}=2.52 \quad p=0.28$} \\
\hline \multicolumn{4}{|c|}{$* *$ melancholic current vs.unaffected $\chi^{2}=2.47 p \mathrm{Val}=0.12$ and $\chi^{2}=0.32 p \mathrm{Met}=0.57$} \\
\hline \multicolumn{4}{|c|}{ *** melancholic past vs. unaffected $\chi^{2}=1.97 p=0.37$} \\
\hline
\end{tabular}

3.3. BDNF Val66Met genotype and allele distributions in melancholic and non-melancholic depressed participants and examining whether the past exposure to SLEs interacts with $B D N F$ to predict the melancholic subtype

In this sample of depressed youths, $27.78 \%$ fulfilled the criteria for melancholic depression. The mean age at interview did not differ significantly between the melancholic and the nonmelancholic subgroups $[\mathrm{t}=-0.28, p$ (two-tailed) $=0.78]$, whereas there was a statistically significant difference $[\mathrm{t}=-0.262, p$ (two-tailed) $=0.01]$ in sex. Further characteristics of the total sample and the subsamples can be found in Table 6 (here we provided an unweighted sum of life events).

Comparison of the total and grouped SLE scores did not show any significant difference between the two patient groups. A nonsignificant difference $[\mathrm{t}=1.759$, df. $=1, p=0.079]$ was found in the intrafamilial SLE scores $(M=17.33$ in the nonmelancholic and 15.62 in the melancholic 
group, respectively). Table 8 shows the frequency of each life event and the life event grouping, together with the relative $p$ - values.

Table 8. Frequency of stressful life events in the melancholic and non-melancholic groups and the p-values of the independent sample t-statistics testing the differences of the SLE scores between those with and without melancholy

Life event groups

$\begin{array}{lr}\text { Frequency in the } & \text { Frequency in the non- } \\ \text { melancholic group } & \text { melancholic group }\end{array}$

$(\mathrm{N}=162) \quad(\mathrm{N}=421)$

\begin{tabular}{|c|c|c|c|c|c|}
\hline & $\mathbf{N}$ & $\%$ & $\mathbf{N}$ & $\%$ & $p$-value \\
\hline \multicolumn{6}{|l|}{ Parental health events } \\
\hline $\begin{array}{l}\text { 1. Medical hospitalization of biological mother } \\
\text { due to somatic illness }\end{array}$ & 49 & 30.2 & 155 & 36.8 & 0.59 \\
\hline 2. Medical hospitalization of biological father & 43 & 26.9 & 116 & 27.6 & \\
\hline 3. Medical. hospitalization of stepparent & 5 & 3.1 & 8 & 1.9 & \\
\hline 4. Physical illness of biological mother & 16 & 9.9 & 46 & 10.9 & \\
\hline 5. Physical illness of biological father & 18 & 11.2 & 33 & 7.8 & \\
\hline 6. Physical illness of stepparent & 0 & 0.0 & 1 & 0.2 & \\
\hline 7. Psychiatric hospitalization of biological mother & 31 & 19.1 & 63 & 15 & \\
\hline 8. Psychiatric hospitalization of biological father & 22 & 13.7 & 57 & 13.5 & \\
\hline 9. Psychiatric hospitalization of stepparent & 0 & 0.0 & 6 & 1.4 & \\
\hline
\end{tabular}

\section{Death of Close Relatives Events}

\begin{tabular}{l|cc|cc|c} 
10. Death of a parent & 10 & 6.2 & 17 & 4.0 & 0.63 \\
11. Death of a close relative & 107 & 66.0 & 286 & 67.9 & 0.40 \\
\hline Sociodemographic Events & 40 & 24.7 & 134 & 31.8 & 52.7 \\
12. Financial problem & 92 & 56.8 & 222 & 48.2 & 3.1 \\
13. Move & 73 & 45.3 & 203 & 4 & \\
14. Parent unemployed & 4 & 2.5 & 13 & 17 & \\
15. Natural disaster & 5 & 3.1 & & & \\
16. Loss of home & & & & \\
\hline
\end{tabular}




\begin{tabular}{l|cc|cc|c}
\hline Intra-familial Events & 102 & 63.0 & 275 & 65.3 & 0.079 \\
17. Sibling birth & 36 & 22.5 & 139 & 33.0 & \\
18. Sibling medical hospitalization & 12 & 7.4 & 33 & 7.8 \\
19. Sibling psychiatric hospitalization & 78 & 48.1 & 225 & 53.4 \\
20. Family arguments & 0 & 0.0 & 4 & 1 \\
21. Foster-care of subject & 61 & 37.7 & 160 & 38.0 & \\
22. Divorce of biological parents & 44 & 27.2 & 114 & 27.1 & 0.92 \\
\hline Extrafamilial Events and Abuse & 88 & 54.3 & 230 & 54.6 & \\
23. Abuse & 6 & 3.7 & 19 & 4.5 & \\
24. Teasing by peers & 3 & 1.9 & 7 & 1.7 & \\
25. Police contact & & & &
\end{tabular}

Grouping is based on the study of Mayer et al. (2009) Ref. 24

SLE, stressful life event

In both melancholic and nonmelancholic depressed groups, the homozygous Val/Val genotype had the highest occurrence. The homozygous Met/Met genotype was the least common in both groups. Table 9 shows the genotype and allele frequencies in the total depressed group and the subgroups. The genotypes were in Hardy-Weinberg equilibrium, both in the total depressed group and in the subgroups.

Table 9. BDNF genotype distributions and allele frequencies in the melancholic and non-melancholic subgroups

Depressed $(\mathrm{N}=583) \quad$ MEL $(\mathrm{N}=162) \quad$ NMEL $(\mathrm{N}=421)$

\begin{tabular}{rccc}
\hline Genotype [n (\%)] & & & \\
Met/Met & $18(3.1)$ & $4(2.5)$ & $14(3.3)$ \\
Val/Met & $167(28.6)$ & $119(73.1)$ & $128(30.4)$ \\
Val/Val & $398(68.3)$ & & $279(66.3)$ \\
Allele [n (\%)] & & $277(85.5)$ & $686(81.5)$ \\
Val & $963(82.6)$ & $47(14.5)$ & $156(18.5)$ \\
Met & $203(17.4)$ &
\end{tabular}

BDNF, brain-derived neurotrophic factor; MEL: Melancholic (either current or past); NMEL: Non-melancholic depressed

Testing our first hypothesis, the allele frequency was not significantly different across the two diagnostic groups (Fisher's exact: $p=0.121$ ). The Val/Val genotype frequency did not differ 
significantly $(\chi 2=2.80, \mathrm{df} .=2, p=0.25)$ between the melancholic and the nonmelancholic group. Because of the low rate of the Met/Met genotype, genotypes were dichotomized on the basis of the presence of the Met allele. There was a trend among the nonmelancholic depressed youth of showing a slightly higher rate of the Met-containing genotype, although not statistically significant (Fisher's exact: $p=0.112$ ). The effect size $(\mathrm{W})$ for our genotype-by-melancholia interaction was 0.12 ; power on such an effect size with 2 df. was 0.74 . Examining our second hypothesis, in the total melancholic group with the Model 1 of the logistic regression, described in the Statistical analysis section, taking Met containing genotypes as the reference category, we did not find either significant main effect or significant interaction effect of the total SLEs and the BDNF polymorphism on the melancholy outcome. When we applied Model 2 (again the Met-containing genotype was considered the reference category) to examine life event groups separately, neither of the events contributed significantly toward the model. Main effects and interactions of BDNF Met-containing genotypes, total SLEs, and SLE groups as predictors in the model of melancholic depression are shown in Table 10. For the logistic regression analysis, power was 0.31 for life events, 0.56 for the presence of a Met allele, and 0.06 for the life eventsby-genotype interaction. 
Table 10. Main effects and interactions of BDNF Met-containing genotypes, total stressful life events, and stressful life event groups as predictors in the model of melancholic depression in males and females

\begin{tabular}{|c|c|c|c|c|}
\hline Dependent variable & Models & Independent variables & OR & $p$ value \\
\hline \multirow[t]{17}{*}{ Melancholy (Females) } & \multirow[t]{3}{*}{ Model 1} & Met-containing genotypes & - & .0789 \\
\hline & & Total stressful life events & - & .733 \\
\hline & & Met-containing genotypes $\times$ Total stressful life events & - & .385 \\
\hline & \multirow[t]{13}{*}{ Model 2} & Met-containing genotypes & - & .391 \\
\hline & & Parental health & - & .893 \\
\hline & & Death of close relatives & - & .187 \\
\hline & & Sociodemographic & - & .631 \\
\hline & & Intrafamilial & - & .111 \\
\hline & & Extrafamilial and Abuse & - & .871 \\
\hline & & Met-containing genotypes $\times$ & & .901 \\
\hline & & Parental health & - & \\
\hline & & Met-containing genotypes $\times$ & & .894 \\
\hline & & Death of close relatives & - & \\
\hline & & Met-containing genotypes $\times$ Sociodemographic & - & .573 \\
\hline & & Met-containing genotypes $\times$ Intrafamilial & - & .126 \\
\hline & & Met-containing genotypes $\times$ Extrafamilial and Abuse & 1.05 & .021 \\
\hline & \multirow{4}{*}{ Model 1} & Met-containing genotypes & - & .073 \\
\hline \multirow[t]{16}{*}{ Melancholy (Males) } & & Total stressful life events & - & .109 \\
\hline & & Met-containing genotypes $\times$ & & .990 \\
\hline & & Total stressful life events & & \\
\hline & \multirow[t]{13}{*}{ Model 2} & Met-containing genotypes & - & .073 \\
\hline & & Parental health & - & .485 \\
\hline & & Death of close relatives & - & .074 \\
\hline & & Sociodemographic & - & .485 \\
\hline & & Intrafamilial & - & .195 \\
\hline & & Extrafamilial and Abuse & - & .419 \\
\hline & & Met-containing genotypes $\times$ & & .995 \\
\hline & & Parental health & - & \\
\hline & & Met-containing genotypes $\times$ & & .964 \\
\hline & & Death of close relatives & 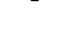 & \\
\hline & & Met-containing genotypes $\times$ Sociodemographic & - & .888 \\
\hline & & Met-containing genotypes $\times$ Intrafamilial & - & .706 \\
\hline & & Met-containing genotypes $\times$ Extrafamilial and Abuse & - & .356 \\
\hline
\end{tabular}


3.4. Investigating the association between interferon gamma $+874 \mathrm{~T} / \mathrm{A}$ polymorphism and the somatic type of depression

In the sickness behaviour (SB) group, the frequencies of the A allele containing genotypes were higher, than in the comparison group, without statistically significant difference (Figure 7) (T/A: SB group: $60.0 \%$, -sb group: $51.1 \%$; A/A: SB group: $21.8 \%$, -sb group: $13.3 \% ; p=0.122$ ).

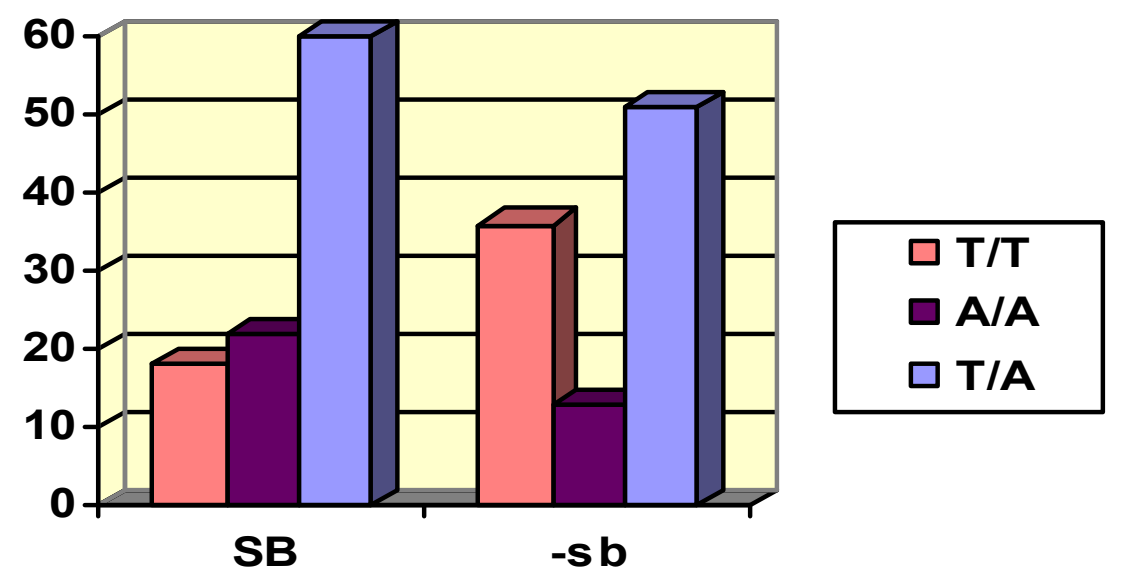

Figure 7. Genotype distribution in probands with and without sickness behaviour $\mathrm{SB}$, sickness behaviour; -sb, comparison group

The comparison of allele frequencies also did not reveal statistically significant differences (T: SB group: 48.2\%, -sb group: 61.1\%; A: SB group: 51.8\%, -sb group: 38.9\%; $p>0.1$ ) (Figure 8).

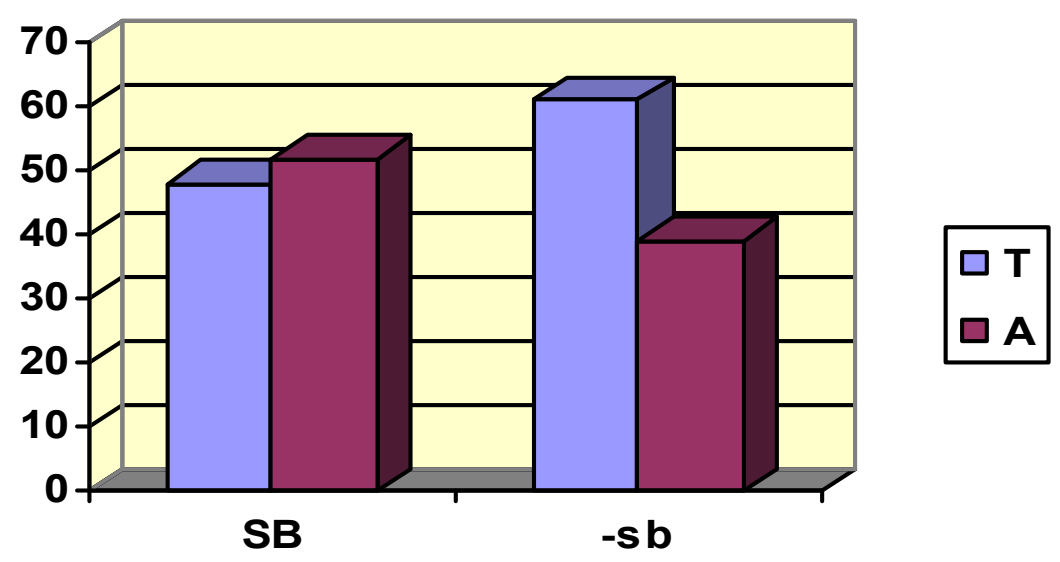

Figure 8. Allele distribution in probands with and without sickness behaviour

$\mathrm{SB}$, sickness behaviour; -sb, comparison group 
These results did not reveal association between $I F N-\gamma+874$ polymorphism and SB. However we observed a tendency, being the genotypes with the A allele more frequent in the SB group.

\section{Discussion}

Our research is performed in a very large clinical sample of children and adolescents with MDD, even involving their siblings who are affected or not affected by the disorder, as controls. Overall, our results complement a growing body of literature, which suggests that MDD is caused by numerous interacting genetic and non-genetic factors. Even today, gene variants associated with MDD vulnerability have not been clearly identified (Lopizzo et al., 2015).

We genotyped single nucleotide polymorphisms across the $O X T$ and $P R L$ genes and their receptors in a large Hungarian cohort of families with COMD. Our results show a trend towards association of two OXT SNPs, rs2740210 and rs4813627, with COMD, not significant after correction for multiple testing. Supplementary analyses initially suggested proband sex effects for $O X T$ SNPs rs2740210 and rs2770378, but were not significant after multiple testing corrections. $O X T$ lies in a segmental duplication region of human chromosome 20 and shares high sequence homology in the first two exons to the arginine vasopressin (AVP) gene. The $O X T$ and $A V P$ genes lie tail-to-tail and are separated by a $10 \mathrm{~kb}$ intergenic region (IGR); $A V P$ and vasopressin $\mathrm{V} 1 \mathrm{~b}$ receptor gene ( $(A V P R 1 B)$ genetic polymorphisms have both been significantly associated with COMD in this sample (Dempster et al., 2007, 2009). The three OXT SNPs genotyped in the present study reside within $2 \mathrm{~kb}$ of the $3^{\prime}$ end of the $O X T$ gene. Transgenic rat and mouse studies of the $O X T$ and $A V P$ genes have shown that the IGR contains regulatory sequences responsible for cell-specific OXT expression in oxytocinergic magnocellular neurons (MCNs) (Murphy and Wells, 2003). The observation that the two OXT SNPs showed a nonsignificant trend for affected daughters, is of note in light of OXT sex effects reported in the literature (Richard and Zingg, 1990; Cushing and Carter, 2000). To our knowledge, this is the first genetic association study of $O X T$ and $P R L$ variants in a pediatric mood disorder sample. Four studies have found associations between $O X T R$ gene variations and autism (Wu et al., 2005; Ylisaukko-oja et al., 2005; Jacob et al., 2007; Gregory et al., 2009) and recent evidence has implicated the OXTR in maternal sensitive responsiveness with their 2-year-old toddlers 
(Bakermans Kranenburg and van Ijzendoorn, 2008). A haplotype of three OXTR SNPs that we did not examine has recently been associated with negative affect and loneliness (Lucht et al., 2009). Another investigation noted an association between two OXTR SNPs and major depression (Costa et al., 2009); we studied three different loci and provided broader SNP coverage of the $O X T R$, with a childhood-onset sample. There were more missing fathers than missing mothers in our sample. We did not estimate missing parental genotypes. Since a missing parental genotype means the entire family is excluded from the analysis, the relatively larger number of missing fathers will reduce our power, but not influence the relative numbers of parental transmissions tested. We studied a moderately large, well-characterized sample. Statistical methods used were robust to population stratification. Corrections for multiple tests were conservative. We estimate 678 families provide a power of 0.86 , given the assumptions of a $\alpha=0.05$, population frequency of $2 \%$, additive model of inheritance, genotype relative risk of 1.4 , minor allele frequency of 0.41 (mean minor allele frequency for $O X T$ SNPs $=0.41$ ) and complete linkage between risk and disease variants (Purcell et al., 2003). We report evidence that was initially suggestive of possible association between two OXT SNPs (rs2740210 and rs4813627) and COMD. The results survived spectral decomposition, but were not significant after correcting for the number of genes tested. OXTR, PRL and PRLR SNPs were not associated with COMD. In secondary analyses, the relative significances of association for two OXT SNPs were increased with parental and proband sex effect analyses. A trend towards proband sex effects to daughters failed to reach statistical significance after correcting for multiple tests. Considering the $O X T$ SNPs are located in a putative regulatory region, our exploratory analyses by parent and proband sex are of interest as they may be relevant to epigenetic effects (Kaminsky et al., 2006).

Our second study completes the investigation of the genetic background of depression using alternative phenotypes. We were particularly interested in finding subtypes/alternative phenotypes of depression, as well as finding a trait marker for major depression, because such factors could be helpful in finding susceptibility genes. Given that MDD as defined by the DSMIV is a complex disorder, finding susceptibility genes may be facilitated using alternative, more homogenous depression phenotypes. However, even factors other than genetic vulnerability and diagnostic procedure must be considered to explain the development of MDD (Hosang et al., 2014). Despite the clinical utility and validity of the melancholic phenotype of depression, a 
debate has been ongoing on the relevance of the subtype, suggesting that further research is needed (Hadzi-Pavlovic and Boyce, 2012) to define its biological features. After that the results of our preliminary study showed that the $B D N F$ Val66Met polymorphism might play a role in the onset of melancholic type of depression, we decided to perform the analyses on a larger database and with improved criteria for melancholic depression.

Consequently, we studied the contribution of the BDNF polymorphism and its interaction with SLE toward early onset melancholic depression. The frequency of melancholia in our sample was in the range of the previously reported prevalences of $20 \%$ to almost $50 \%$ in juvenile samples (Ryan et al., 1987; Kolvin et al., 1991; Ambrosini et al., 2002). The ratio of females was significantly higher in the melancholic than in the non-melancholic group $[\mathrm{t}=$ $-0.262, p$ (two-tailed) $=0.01]$, suggesting that females are more prone to developing the earlyonset melancholic phenotype. The current literature establishes that girls show more depressive symptoms than boys (Wade et al., 2002; Hankin et al., 2007); however, there is some inconsistency in the findings (Chen et al., 2012), which may be because of methodological, age, and ethnic differences in the sample populations. Although in a preliminary study of Quinn et al. (2012) and in the study of Guo et al. (2015), no significant differences were found in the melancholic, non-melancholic, and control groups for sex or age, the difference compared with our findings may be because of their focus on the adult population in addition to a smaller sample size, which decreases the chances of finding a significant difference. Our result may represent an interesting suggestion for future research as the presence of the subtype might influence treatment response (Rush et al., 2008) and complications. According to a study of Gold et al. (2002), common medical complications of different subtypes of depression may occur because of different underlying mechanisms. In the genotypic and allelic association analysis, we found elevated Val/Val genotype frequency in the melancholic group. Our analysis, however, could not be used to discriminate between the melancholic and the non-melancholic groups. The calculated effect size and the power analysis carried out for our genotype-by-melancholia interaction suggests that small to medium effects would have been detected if present. Our results partly correlate with the study of Quinn et al. (2012), showing that no significant relationship was found between the BDNF genotype and groups. However, they found that the gene-by-environment interaction effect is expected to provide a better prediction for melancholic depression. The explanation for the different but not contradictory results is that we examined 
biological features discriminating the melancholic versus the non-melancholic phenotype within a depressed sample, whereas Quinn et al. (2012) compared the melancholic and the nonmelancholic group of patients with healthy controls. Power analysis for the logistic regression analysis suggests that our sample was adequate to detect the main effects of life events or genotype if they were medium to large, but could only detect interaction effects if they were quite large.

In our third study we investigated the $(+874) \mathrm{T} / \mathrm{A}$ genotypes given the information that they have previously been studied in connection with the risk of IFN-alpha-induced depression, the presence of $\mathrm{T}$ alleles representing a risk for the development of this disease (Oxenkrug et al., 2014). Our case control study investigating directly the role of interferon- $\gamma$, performed on a welldefined subgroup of depressed children, however, did not reveal any significant difference in the genotype or allele distribution between subjects with the somatic type of depression and the comparison group. We observed a tendency that failed to attain significance at conventional level, being the genotypes with the A allele more frequent in the SB group. Further investigation may thus be needed with an increased number of subjects.

Since the underlying genetics has proved to be highly complex, identifying the genetic determinants for individual differences in the susceptibility to MDD is amongst the greatest challenges.

An illustrative example on the complexity of the genetic background of depression is given by that interferon treatment may modulate 5-HTT activity levels (Morikawa et al., 1998). A repeat length polymorphism in the promoter region of this gene has been shown to affect the rate of serotonin uptake and may play a role in depression-susceptibility. In human placental choriocarcinoma cells, a 3-hour treatment with IFN- $\gamma$ increased levels of 5-HTT mRNA and a treatment with IFN- $\gamma$ for 3-6 hours also increased 5-HTT uptake activity. These data suggest that IFN-induced psychiatric effects may be modulated by regulation of 5-HTT transcription.

The power and performance of the methods trying to determine the molecular genetic background of depression may be further improved by integrating biological information at the systemic level. To overcome the limitations of the case control approaches, sets of the genes carrying out biochemical processes related to the functioning of neural systems can be investigated in the future. 


\section{Strengths and Limitations}

Although the sample size would ideally be larger, the above described studies have several methodological strengths. We note that our melancholic group is a well-defined subgroup within the depressed patients thanks to the diagnoses established through a very rigorous procedure, described in the materials and methods section, using clinician administered semistructured interviews to obtain the optimal collection of biographical and contextual information. Life events were measured by researcher administered questionnaires. The present study on oxytocin and prolactin genes is the first genetic analysis to examine the association between variants in these neuroendocrine genes and depression with onset in childhood. Furthermore, to our knowledge, this is the first study to investigate the differentiating effect of the $B D N F$ genotype and the $\mathrm{G} \times \mathrm{E}$ interaction on the melancholic phenotype in a large sample of depressed young patients, which was representative of the Hungarian population.

As the parents were providing information on their children's SLEs, we had limited information on some of them, for example teasing. Though face-to-face interviews by clinically trained assessors, the use of common phrases, and the use of timelines with named "anchors" during the interview may facilitate retrospective recall (Buka et al., 2004).

Given the complexity of Model 2 investigating the interaction of stressful life events with the BDNF Val66Met polymorphism, the particular model would only be able to detect large effects, which represents a limitation of our study. 


\section{Conclusions}

We found no association between oxytocin and prolactin gene variants and childhoodonset mood disorders. The performed exploratory analyses by parent and proband sex are of interest as they may be relevant to epigenetic effects. We didn't find association between the melancholic subtype of major depression and the $B D N F$ genotype and stressful life event interaction and the somatic subtype of childhood-onset major depression and the interferongamma $+874 \mathrm{~T} / \mathrm{A}$ polymorphism in this clinic-referred population of depressed youths.

In our study, females are more prone to develop the early-onset melancholic phenotype. This results contributes to the prevention and treatment of the melancholic type of childhoodonset major depression, as consequences can be lessened by focusing on risk groups in early stages. However, additional research and empirical work is needed in this area to further understand the contribution of the early-onset phenotype. 


\section{Acknowledgements}

The financial supports of the National Institute of Mental Health by Program Project \# P01 MH056193, MH084938 HHS, Washington, DC and a SickKids Foundation-CIHR New Investigator Grant are gratefully acknowledged. Members of the International Consortium for Childhood-Onset Mood Disorders. Heads of the Units and Departments where the patients were collected, and collaborators. I would like to sincerely acknowledge my gratitude to my supervisors Ágnes Vetró and Krisztina Kapornai, for their guidance and support throughout the research work. I would like to express my sincere gratitude to Maria Kovacs for the continuous support of my Ph.D. study and related research. I would also like to thank Anna Juhász, Ágnes Fehér, Enikő Kiss, Ildikó Baji and István Benák for their fruitful collaboration. I would like to thank all my colleagues at Szeged University Medical Faculty, Department of Child and Adolescent Psychiatry, Szeged. I would like to thank Fabrizio for believing in me and being by my side throughout this time. I would also like to thank my family for always being supportive and encouraging.

Tímea

Szeged, 2016 


\section{References}

Ambrosini, PJ, Bennett, DS, Cleland, CM, Haslam, N. (2002). Taxonicity of adolescent melancholia: A categorical or dimensional construct. J Psychiat Res 36, 247-256.

American Psychiatric Association (APA). (1987). Diagnostic and Statistical manual of mental disorders, 3rd ed. Washington DC: APA.

American Psychiatric Association (APA). (1994). Diagnostic and statistical manual of mental disorders, 4th ed. Washington DC: APA.

Amico, JA, Mantella, RC, Vollmer, RR, Li, X. (2004). Anxiety and stress responses in female oxytocin deficient mice. J. Neuroendocrinol 16, 319-324.

Anderson, IM, Ware, CJ, da Roza Davis, JM, Cowen, PJ. (1992). Decreased 5-HT-mediated prolactin release in major depression. Br. J. Psychiatry 160, 372-378.

Bakermans-Kranenburg, MJ, van Ijzendoorn, MH. (2008). Oxytocin receptor (OXTR) and serotonin transporter (5-HTT) genes associated with observed parenting. Soc Cogn Affect Neurosci 3, 128-134.

Barrett, JC, Fry, B, Maller, J, Daly, MJ. (2005). Haploview: analysis and visualization of LD and haplotype maps. Bioinformatics 21, 263-265.

Bell, CJ, Nicholson, H, Mulder, RT, Luty, SE, Joyce, PR. (2006). Plasma oxytocin levels in depression and their correlation with the temperament dimension of reward dependence. $\mathrm{J}$. Psychopharmacol 20, 656-660. 
Bennabi, D, Vandel, P, Papaxanthis, C, Pozzo, T, Haffen, E. (2013). Psychomotor Retardation in Depression: A Systematic Review of Diagnostic, Pathophysiologic, and Therapeutic Implications. Biomed Res Int 2013, 158-746.

Bodnàr, I, Mravek, B, Kubovcakova, L, Fekete, MI, Nagy, GM, Kvetnansky, R. (2004). Immobilization stress-induced increase in plasma catecholamine levels is inhibited by a prolactoliberin (salsolinol) administration. Ann N Y Acad Sci 1018, 124-130.

Bosker, FJ, Hartman, CA, Nolte, IM, et al. (2011). Poor replication of candidate genes for major depressive disorder using genome-wide association data. Mol Psychiatry 16, 516-32.

Bouma, E, Ormel, J, Verhulst, F, Oldehinkel, A. (2008). Stressful life events and depressive problems in early adolescent boys and girls: The influence of parental depression, temperament, and family environment. J Affect Disord 105(1-3), 185-193.

Bracht, T, Horn, H, Strik, W, Federspiel, A, Schnell, S, Höfle, O, Stegmayer, K, Wiest, R, Dierks, T, Müller, TJ, Walther, S. (2014). White matter microstructure alterations of the medial forebrain bundle in melancholic depression. J Affect Disord 155, 186-93.

Brown, G. W, Craig, TKJ, Harris, TO, Herbert, J, Hodgson, K, Tansey, KE and Uher, R. (2014). Functional polymorphism in the brain-derived neurotrophic factor gene interacts with stressful life events but not childhood maltreatment in the etiology of depression. Depress Anxiety 31, 326-334.

Brummett, BH, Boyle, SH, Kuhn, CM, Siegler, IC, Williams, RB. (2008). Associations among central nervous system serotonergic function and neuroticism are moderated by gender. Biol Psychol 78, 200-203.

Buka, SL, Goldstein, JM, Spartos, E, Tsuang, MT. (2004). The retrospective measurement of prenatal and perinatal events: Accuracy of maternal recall. Schizophr Res. 71:417-426. 
Bukh, JD, Bock, C, Vinberg, M, Werge, T, Gether U, Vedel, Kessing, L. (2009). Interaction between genetic polymorphisms and stressful life events in first episode depression. J Affect Disord 119(1-3), 107-15.

Caspi, A, Sugden, K, Moffitt, TE, Taylor, A, Craig, IW, Harrington, H, McClay, J, Mill, J, Martin, J, Braithwaite, A, Poulton, R. (2003). Influence of life stress on depression: moderation by a

polymorphism in the 5-HTT gene. Science 301, 386-389.

Cardoner, N, Soria, V, Gratacos, M, Hernandez-Ribas, R, Pujol, J, et al. (2013). Val66met BDNF genotypes in melancholic depression: effects on brain structure and treatment outcome. Depress Anxiety 30, 225-233.

Chen, L, Lawlor, DA, Lewis, SJ, Yuan, W, Abdollahi, MR, Timpson, NJ, Day, IN, Ebrahim, S, Smith, GD, Shugart, YY. (2008). Genetic association study of BDNF in depression: Finding from two cohort studies and a meta-analysis. Am J Med Genet (Neuropsychiatr Genet) 147, 814 821.

Chen, J, Li, X, \& McGue, M. (2012). Interacting effect of BDNF Val66Met polymorphism and stressful life events on adolescent depression. Genes, Brain and Behaviour 11, 958-965.

Chen J, Li X, McGue M. (2013). The interacting effect of the BDNF Val66Met polymorphism and stressful life events on adolescent depression is not an artifact of gene-environment correlation: evidence from a longitudinal twin study. J Child Psychol Psychiatry 54(10), 10661073.

Costa, B, Pini, S, Gabelloni, P, Abelli, M, Lari, L, Cardini, A, et al. (2009). Oxytocin receptor polymorphisms and adult attachment style in patients with depression. Psychoneuroendocrinology

34, 1506-1514. 
Cuijpers P, Smit F. (2002) Excess mortality in depression: a meta-analysis of community studies. J Affect Disord 72(3), 227-236.

Cushing, BS, Carter, CS. (2000). Peripheral pulses of oxytocin increase partner preferences in female, but not male, prairie voles. Horm Behav 37, 49-56.

Cyranowski, JM, Hofkens, TL, Frank, E, Seltman, H, Cai, HM, Amico, JA. (2008). Evidence of dysregulated peripheral oxytocin release among depressed women. Psychosom Med 70, 967975.

Dantchev, N, Widlöcher, DJ. (1998). The measurement of retardation in depression. J Clin Psychiatry 59 Suppl 14, 19-25.

Dempster, EL, Burcescu, I, Wigg, K, Kiss, E, Baji, I, Gadoros, J, Tamàs, Z, Kapornai, K, Daróczy, G, Kennedy, JL, et al. (2009). Further genetic evidence implicates the vasopressin system in childhood-onset mood disorders. Eur J Neurosci 30, 1615-1619.

Dempster, EL, Burcescu, I, Wigg, K, Kiss, E, Baji, I, Gadoros, J, Tamás, Z, Kennedy, JL, et al. (2007). Evidence of an association between the vasopressin V1b receptor gene (AVPR1B) and childhood-onset mood disorders. Arch. Gen. Psychiatry 64, 1189-1195.

Domes, G, Heinrichs, M, Glascher, J, Buchel, C, Braus, DF, Herpertz, SC. (2007). Oxytocin attenuates amygdala responses to emotional faces regardless of valence. Biol Psychiatry 62, 1187-1190.

Domschke, K, Lawford, B, Laje, G, Berger, K, Young, R, Morris, P, Deckert, J, Arolt, V, McMahon, FJ, Baune, BT. (2010). Brain-derived neurotrophic factor ( BDNF) gene: no major impact on antidepressant treatment response. Int. J. Neuropsychop 13, 93-101. 
Drago, F, Pulvirenti, L, Spadaro, F, Pennisi, G. (1990). Effects of TRH and prolactin in the behavioural despair (swim) model of depression in rats. Psychoneuroendocrinology 15, 349-356.

Dudbridge, F. (2003). Pedigree disequilibrium tests for multilocus haplotypes. Genet Epidemiol $25,115-121$.

Ebmeier KP, Donaghey C, Steele JD. (2006). Recent developments and current controversies in depression. Lancet 367(9505), 153-167.

Ebner, K, Bosch, OJ, Kromer, SA, Singewald, N, Neumann, ID. (2005). Release of oxytocin in the rat central amygdala modulates stress-coping behaviour and the release of excitatory amino acids. Neuropsychopharmacology 30, 223-230.

Egan MF, Kojima M, Callicott JH, Goldberg TE, Kolachana BS, Bertolino A, et al. (2003). The BDNF val66met polymorphism affects activity-dependent secretion of BDNF and human memory and hippocampal function. Cell 112, 257-269.

Eley, TC, Sugden, K, Corsico, A, Gregory, AM, Sham, P, McGuffin, P, Plomin, R, Craig, IW. (2004). Gene-environment interaction analysis of serotonin system markers with adolescent depression. Mol Psychiatry 9, 908-915.

Elzinga, BM, Molendijk, ML, Oude Voshaar, RC, Bus, BA, Prickaerts, J, Spinhoven, P, Penninx, BJ. (2011). The impact of childhood abuse and recent stress on serum brain-derived neurotrophic factor and the moderating role of BDNF Val66Met. Psychopharmacology (Berl,) 214(1), 319-28.

Emiliano, AB, Cruz, T, Pannoni, V, Fudge, JL. (2007). The interface of oxytocin-labeled cells and serotonin transporter-containing fibers in the primate hypothalamus: a substrate for SSRIs therapeutic effects? Neuropsychopharmacology 32, 977-988. 
Faul F, Erdfelder E, Lang A-G, Buchner A (2007). G*Power 3: a flexible statistical power analysis program for the social, behavioural, and biomedical sciences. Behav Res Methods 39, $175-191$.

Fent K, Zibinden G. (1987). Toxicity of Interferon and Interleukin. TIPS 8, 100-5.

Gabbay V, Klein R, Alonso C, Babb J, Nishawala M, De Jesus G, Hirsch G, Hottinger-Blanc P, Gonzalez C. (2009). Immune system dysregulation in adolescent major depressive disorder. Journal of Affective Disorders 115;177-182.

Gabriel, SB, Schaffner, SF, Nguyen, H, Moore, JM, Roy, J, Blumenstiel, B. (2002). The structure of haplotype blocks in the human genome. Science 296, 2225-2229.

Geller, B, Craney, JL, Bolhofner, K, DelBello, M, Williams, M, Zimerman, B. (2001). Bipolar disorder at prospective follow-up of adults who had prepubertal major depressive disorder. Am J Psychiatry 158, 125-127.

Gold, PW, Gabry, KE, Yasuda, MR, Chrousos, GP. (2002). Divergent endocrine abnormalities in melancholic and atypical depression: clinical and pathophysiologic implications. Endocrin Metab Clin 31(1), 37-62.

Golden, RN, Ekstrom, D, Brown, TM, Ruegg, R, Evans, DL, Haggerty Jr, JJ, Garbutt, JC, Pedersen, CA, Mason, GA, Browne, J, et al. (1992). Neuroendocrine effects of intravenous clomipramine in depressed patients and healthy subjects. Am J Psychiatry 149, 1168-1175.

Gregory, SG, Connelly, JJ, Towers, AJ, Johnson, J, Boscocho, D, Markunas, CA, et al. (2009). Genomic and epigenetic evidence for oxytocin receptor deficiency in autism. BMC Med 7, 62 .

Guo, CC, Nguyen VT, Hyett MP, Parker GB, Breakspear, MJ. (2015). Out-of-sync: disrupted neural activity in emotional circuitry during film viewing in melancholic depression. Scientific Reports 5, 11605. 
Hadzi-Pavlovic, D, Boyce, P. (2012). Melancholia. Curr Opin Psychiatr 25(1), 14-18.

Hankin, BL, Mermelstein, R, Roesch, L. (2007) Sex differences in adolescent depression: Stress exposure and reactivity models. Child Development. 78:279-295.

Happonen, M, Pulkkinen, L, Kaprio, J, Van der Meere, J, Viken, RJ, Rose, RJ. (2002). The heritability of depressive symptoms: multiple informants and multiple measures. J. Child. Psychol. Psychiatry 43, 471-479.

Harkness, KL, Monroe, SM. (2006). Severe melancholic depression is more vulnerable than nonmelancholic depression to minor precipitating life events. J Affect Disord 91, 257-263.

Hasler, G, Drevets, WC, Manji, HK, Charney, DS. (2004). Discovering endophenotypes for major depression. Neuropsychopharmacology, 29(10), 1765-1781.

Heninger, GR, Charney, DS, Sternberg, DE. (1984). Serotonergic function in depression. Prolactin response to intravenous tryptophan in depressed patients and healthy subjects. Arch Gen Psychiatry 41, 398-402.

Hosang, GM, Shiles, C, Tansey, KE, McGuffin, P, Uher, R. (2014) Interaction between stress and the BDNF Val66Met polymorphism in depression: a systematic review and meta-analysis. BMC Med 16, 12-17.

Huang, YY, Battistuzzi, C, Oquendo, MA, Harkavy-Friedman, J, Greenhill, L, Zalsman, G, Brodsky, B, Arango, V, Brent, DA, Mann, JJ. (2004). Human 5-HT1A receptor C(-1019)G polymorphism and psychopathology. Int J Neuropsychopharmacol 7, 441—451.

Hudziak, JJ, Rudiger, LP, Neale, MC, Heath, AC, Todd, RD. (2000). A twin study of inattentive, aggressive, and anxious/depressed behaviours. J Am Acad Child Adolesc Psychiatry 39, 469476. 
Hyett, MP, Parker, GB, Proudfoot, J, Fletcher, K. (2008). Examining age effects on prototype melancholic symptoms as a strategy for refining definition of melancholia. J Affect Disord 109, 193-197.

Jacob, S, Brune, CW, Carter, CS, Leventhal, BL, Lord, C, Cook Jr, EH. (2007). Association of the oxytocin receptor gene (OXTR) in Caucasian children and adolescents with autism. Neurosci Lett 417, 6-9.

Joyce, PR, Mulder, RT, Luty, SE, McKenzie, JM, Rae, AM. (2003). A differential response to nortriptyline and fluoxetine in melancholic depression: the importance of age and gender. Acta Psychiatr Scand 108, 20-23.

Kaminsky, Z, Wang, SC, Petronis, A. (2006). Complex disease, gender and epigenetics. Ann Med 38, 530-544.

Kapornai, K, Gentzler, AL, Tepper, P, Kiss, E, Mayer, L, Tamas, Z, Kovacs, M, Vetro, A, International Consortium for ChildhoodOnset Mood Disorders. (2007). Early developmental characteristics and features of major depressive disorder among child psychiatric patients in Hungary. J Affect Disord 100, 91-101.

Kaufman, J, Yang, BZ, Douglas-Palumberi, H, Houshyar, S, Lipschitz, D, Krystal, JH, et al. (2004). Social supports and serotonin transporter gene moderate depression in maltreated children. Proc Natl Acad Sci U S A. 101(49), 17316-17321.

Kendler, KS, Gatz, M, Gardner, CO, Pedersen, NL. (2006). A Swedish national twin study of lifetime major depression. Am J Psychiatry 163(1), 109-14.

Kessler, RC. (1997a). The effects of stressful life events on depression. Annu Rev Psychol 48, 191-214. 
Kessler, RC. (1997b). The diagnostic validity of melancholic major depression in a populationbased sample of female twins. Arch Gen Psychiat 54, 299-304.

Kim, JM, Stewart, R, Kim, SW, Yang, SJ, Shin, IS, Kim, YH, Yoon, JS. (2007). Interactions between life stressors and susceptibility genes (5-HTTLPR and BDNF) on depression in Korean elders. Biol Psychiat 62(5), 423-28.

Kirsch, P, Esslinger, C, Chen, Q, Mier, D, Lis, S, Siddhanti, S, Gruppe, H, Mattay, VS, Gallhofer, B, Meyer-Lindenberg, A. (2005). Oxytocin modulates neural circuitry for social cognition and fear in humans. J Neurosci 25, 11489-11493.

Kiss, E, Gentzler, AM, George, C, Kapornai, K, Tamas, Z, Kovacs, M, Vetro, A. (2007). Factors influencing mother-child reports of depressive symptoms and agreement among clinically referred depressed youngsters in Hungary. J Affect Disord 100, 143-151.

Kokay, IC, Bull, PM, Davis, RL, Ludwig, M, Grattan, DR. (2006). Expression of the long form of the prolactin receptor in magnocellular oxytocin neurons is associated with specific prolactin regulation of oxytocin neurons. Am J Physiol Regul Integr Comp Physiol 290, R1216—R1225.

Kolvin, I, Barrett, LM, Bhate, SR, Berney, TP, Famuyiwa, OO, Fundudis, T, et al. (1991). Issues in the diagnosis and classification of childhood depression. Brit J Psychiat 159 (Suppl 11), 9-11.

Kovacs, M, Devlin, B, Pollock, M, Richards, C, Mukerji, P. (1997). A controlled family history study of childhood-onset depressive disorder. Arch Gen Psychiatry 54, 613-623.

Kovacs M. (2003) Children's Depression Inventory (CDI): Technical Manual Update, Toronto, Canada: Multi-Health Systems.

Lahiri, DK, Nurnberger Jr, JI. (1991). A rapid non-enzymatic method for the preparation of HMW DNA from blood for RFLP studies. Nucleic Acids Res 19, 5444. 
Lee, R, Garcia, F, van de Kar, LD, Hauger, RD, Coccaro, EF. (2003). Plasma oxytocin in response to pharmaco-challenge to Dfenfluramine and placebo in healthy men. Psychiatry Res $118,129-136$.

Legros, JJ. (2001). Inhibitory effect of oxytocin on corticotrope function in humans: are vasopressin and oxytocin ying-yang neurohormones? Psychoneuroendocrinology 26, 649-655.

Lemonde, S, Turecki, G, Bakish, D, Du, L, Hrdina, PD, Bown, CD, Sequeira, A, Kushwaha, N, Morris, SJ, Basak, A, Ou, XM, Albert, PR. (2003). Impaired repression at a 5-hydroxytryptamine 1 A receptor gene polymorphism associated with major depression and suicide. J Neurosci 23, 8788-8799.

Levinson DF. The genetics of depression: a review. (2006). Biol Psychiatry 60(2), 84-92.

Liu, JW, Ben-Jonathan, N. (1994). Prolactin-releasing activity of neurohypophysial hormones: structure-function relationship. Endocrinology 134, 114-118.

Liu, X, Gentzler, AL, Tepper, P, Kiss, E, Kothencne, VO, Tamas, Z, Vetro, A, Kovacs, M. (2006). Clinical features of depressed children and adolescents with various forms of suicidality. J Clin Psychiatry 67, 1442-1450.

Lopizzo, N, Bocchio Chiavetto, L, Cattane, N, Plazzotta, G, Tarazi, FI, Pariante, CM, Riva, MA, Cattaneo, A. (2015). Gene-environment interaction in major depression: focus on experiencedependent biological systems. Front Psychiatry 6, 68.

Lotrich, FE, Pollock, BG. (2004). Meta-analysis of serotonin transporter polymorphisms and affective disorders. Psychiatr Genet 14, 121-129.

Lucht, MJ, Barnow, S, Sonnenfeld, C, Rosenberger, A, Grabe, HJ, Schroeder, W, Volzke, H, et al. (2009). Associations between the oxytocin receptor gene (OXTR) and affect, loneliness and intelligence in normal subjects. Prog Neuropsychopharmacol Biol Psychiatry 33, 860-866. 
Mann, JJ, McBride, PA, Malone, KM, DeMeo, M, Keilp, J. (1995). Blunted serotonergic responsivity in depressed inpatients. Neuropsychopharmacology 13, 53-64.

Maes, M, Maes, L, Schotte, C, Vandewoude, M, Martin, M, D’Hondt, P, et al. (1990). Clinical subtypes of unipolar depression: Part III, Quantitative differences in various biological markers between the cluster-analytically generated nonvital and vital depression classes. Psychiat Res 34, $59-75$.

Mayer, L, Kiss, E, Baji, I, Skultéti, D, Vetró, Á. (2006). Relationship of depressive symptoms and life events in a school-age population. Psychiatr Hung, 3: 210-218.

Mayer, L, Lopez-Duran, NL, Kovacs, M, George, C, Baji, I, Kapornai, K, Kiss, E, Vetro, A. (2009). Stressful Life Events in a Clinical Sample of Depressed Children in Hungary. J Affect Disord 115(1-2), 207-214.

Maziade, M, Roy, MA, Fournier, JP, Cliche, D, Merette, C, Caron, C, Garneau, Y, Montgrain, N, Shriqui, C, Dion, C. (1992). Reliability of best-estimate diagnosis in genetic linkage studies of major psychoses: results from the Quebec pedigree studies. Am J Psychiat 149, 1674-1686.

McGuffin, P, Rijsdijk, F, Andrew, M, Sham, P, Katz, R, Cardno, A. (2003). The heritability of bipolar affective disorder and the genetic relationship to unipolar depression. Arch Gen Psychiatry 60, 497-502.

Michopoulos, I, Zervas, IM, Pantelis, C, Tsaltas, E, Papakosta, VM, Boufidou, F, Nikolaou, C, Papageorgiou, C, Soldatos, CR, Lykouras, L. (2008). Neuropsychological and hypothalamicpituitary-axis function in female patients with melancholic and non-melancholic depression. Eur Arch Psy Clin N 258, 217-225.

Miller, SA, Dykes, DD, Polesky, HF. (1988). A simple salting out procedure for extracting DNA from human nucleated cells. Nucleic Acids Res 16(3), 1215. 
Misener VL, Gomez L, Wigg KG, Luca P, King N, Kiss E, Daróczi G, Kapornai K, Tamas Z, Mayer L, Gádoros J, Baji I, Kennedy JL, Kovacs M, Vetró Á, Barr CL and the International Consortium for Childhood-Onset Mood Disorders. (2008). Cytokine Genes TNF, IL1A, IL1B, IL6, IL1RN and IL10, and Childhood-Onset Mood Disorders. Neuropsychobiology 58, 71-80.

McMahon, FJ, Buervenich, S, Charney, D, Lipsky, R, Rush, AJ, Wilson, AF, Sorant, AJ, Papaniclaou, GJ, Laje, G, Fava, M,et al. (2006). Variation in the gene encoding the serotonin 2A receptor is associated with outcome of antidepressant treatment. Am J Hum Genet 78, 804-814.

Mitchell, J, McCauley, E, Burke, P, Calderon, R, Schloredt, K. (1989). Psychopathology in parents of depressed children and adolescents. J Am Acad Child Adolesc Psychiatry 28, $352-$ 357.

Morikawa O, Sakai N, Obara H, Saito N. (1998). Effects of interferon-alpha, interferon-gamma and cAMP on the transcriptional regulation of the serotonin transporter. Eur J Pharmacol. 349, 317-324.

Mufson, L, Weissman, MM, Warner, V. (1992). Depression and anxiety in parents and children: a direct interview study. J Anxiety Disorders 6, 1-13.

Murphy, D, Wells, S. (2003). In vivo gene transfer studies on the regulation and function of the vasopressin and oxytocin genes. J Neuroendocrinol 15, 109-125.

Myint AM, Bondy B, Baghai TC, Eser D, Nothdurfter C, Schule C, Zill P, Muller N, Rupprecht R, Schwarz MJ. (2013). Tryptophan metabolism and immunogenetics in major depression: A role for interferon- $\gamma$ gene. Brain Behav Immun 31, 128-133.

Nyholt, DR. (2004). A simple correction for multiple testing for single-nucleotide polymorphisms in linkage disequilibrium with each other. Am J Hum Genet 74, 765-769. 
Oxenkrug GF, Turski W, Zgrajka W, Weinstock J, Ruthazer R, Summergrad P. (2014). Disturbances of tryptophan metabolism and risk of depression in HCV patients treated with IFNalpha. J Infect Dis Ther 2(2), 131.

Ozan, E, Okur, H, Eker, C, Eker, OD, Gonul, AS, Akarsu, N. (2010). The effect of depression, BDNF gene val66met polymorphism and gender on serum BDNF levels. Brain Res Bull 1:6165.

Papakostas, GL, Miller, KK, Peterson, T, Sklarsky, KG, Hilliker, SE, Klibanski, A, Fava, M. (2006). Serum prolactin levels among outpatients with major depressive disorder during the acute phase of treatment with fluoxetine. J Clin Psychiatry 67, 952-957.

Parker, G, Paterson, A. (2014). Melancholia: definition and management. Curr Opin Psychiatry $27(1), 1-6$

Parker G, Hadzi-Pavlovic D (1996). Melancholia: A Disorder of Movement and Mood. New York: Cambridge University Press.

Parsey, RV, Oquendo, MA, Ogden, RT, Olvet, DM, Simpson, N, Huang, YY, Van Heertum, RL, Arango, V, Mann, JJ. (2006). Altered serotonin 1A binding in major depression: a [carbonyl-C11]WAY100635 positron emission tomography study. Biol Psychiatry 59, 106-113

Patas, K, Penninx, BW, Bus, BA, Vogelzangs, N, Molendijk, ML, Elzinga, BM, Bosker, FJ, Oude, Voshaar RC. (2014). Association between serum brain-derived neurotrophic factor and plasma interleukin-6 in major depressive disorder with melancholic features. Brain Behav Immun 36, 71-9.

Pravica V, Perrey C, Stevens A, Lee J-H, Hutchinson IV. (2000). A Single Nucleotide Polymorphism in the First Intron of the Human IFN- $\gamma$ Gene: Absolute Correlation with a Polymorphic CA Microsatellite Marker of High IFN- $\gamma$ Production. Human Immunology 61(9), 863-866. 
Purcell, S, Cherny, SS, Sham, PC. (2003). Genetic Power Calculator: design of linkage and association genetic mapping studies of complex traits. Bioinformatics 19, 149-150.

Quinn CR, Dobson-Stone C, Outhred T, Harris A, Kemp AH (2012). The contribution of BDNF and 5-HTT polymorphisms and early life stress to the heterogeneity of major depressive disorder: a preliminary study. Aust N Z J Psychiatry 46, 55-63.

Rice, F, Harold, G, Thapar, A. (2002). Assessing the effects of age, sex, and shared environment on the genetic aetiology of depression in childhood and adolescence. Journal of Child Psychology and Psychiatry and Allied Disciplines. 43(8), 1039-1051.

Rice, F. (2010). Genetics of childhood and adolescent depression: insights into etiological heterogeneity and challenges for future genomic research. Genome Med 2(9), 68.

Richard, S, Zingg, HH. (1990). The human oxytocin gene promoter is regulated by oestrogens. J Biol Chem 265, 6098-6103.

Risch, N, Herrell, R, Lehner, T, Liang, KY, Eaves, L, Hoh, J, Griem, A, Kovacs, M, Ott, J, Merikangas, KR. (2009). Interaction between the serotonin transporter gene (5-HTTLPR), stressful life events, and risk of depression: a meta-analysis. 301(23), 2462-71.

Rush, AJ, Wisniewski, SR, Warden, D, Luther, JF, Davis, LL, Fava, M, Nierenberg, AA, Trivedi, MH. (2008). Selecting among second-step antidepressant medication monotherapies: predictive value of clinical demographic or first-step treatment features. Arch Gen Psychiat 65(8), 870-80.

Ryan, ND, Puig-Antich, J, Ambrosini, P, Rabinovich, H, Robinson, D, Nelson, B, et al. (1987). The clinical picture of major depression in children and adolescents. Arch Gen Psychiat 44(10), 854-861. 
Savitz, JB, Drevets, WC. (2009). Imaging Phenotypes of Major Depressive Disorder: Genetic Correlates. Neuroscience 164(1), 300-330.

Scantamburlo, G, Hansenne, M, Fuchs, S, Pitchot, W, Marechal, P, Pequeux, C, Ansseau, M, Legros, JJ. (2007). Plasma oxytocin levels and anxiety in patients with major depression. Psychoneuroendocrinology 32, 407-410.

Schotte, CK, Maes, M, Cluydts R, Cosyns, P. (1997). Cluster analytic validation of the DSM melancholic depression: the threshold model: integration of quantitative and qualitative distinctions between unipolar depressive subtypes. Psychiat Res 71(3), 181-195.

Sen, S, Duman, R, Sanacora, G. (2008). Serum BDNF, Depression and Anti-Depressant Medications: Meta-Analyses and Implications. Biol Psychiatry 64(6), 527-532

Sherrill, JT, Kovacs, M. (2000). Interview schedule for children and adolescents (ISCA). J Am Acad Child Adolesc Psychiatry 39, 67-75.

Shyn, SI, Shi, J, Kraft, JB, Potash, JB, Knowles, JA, Weissman, MM, et al. (2011). Novel loci for major depression identified by genome-wide association study of sequenced treatment alternatives to relieve depression and meta-analysis of three studies. Mol Psychiatry 16, 202 215.

Shyn, SI, Hamilton, SP. (2010). The genetics of major depression: moving beyond the monoamine hypothesis. Psych Clin North Am 33(1), 125-140.

Sibolboro Mezzacappa, E, Endicott, J. (2007). Parity mediates the association between infant feeding method and maternal depressive symptoms in the postpartum. Arch. Womens Ment Health 10, 259-266.

Smoller, JW. (2016). The Genetics of Stress-Related Disorders: PTSD, Depression, and Anxiety Disorders. Neuropsychopharmacology. 41(1):297-319. 
Strauss, J, Barr, CL, George, CJ, King, N, Shaikh, S, Devlin, B, Kovacs, M, Kennedy, JL. (2004). Association study of brain-derived neurotrophic factor in adults with a history of childhood onset mood disorder. Am J Med Gen (Neuropsychiatric Genetics) 131, 16-19.

Strauss, J, Barr, CL, George, CJ, Devlin, B, Vetro, A, Kiss, E, Baji, I, King, N, Shaikh, S, Lanktree, M, Kovacs, M, Kennedy, JL and the International Consortium for Childhood-Onset Mood Disorders. (2005). Brain-derived neurotrophic factor variants are associated with childhood-onset mood disorder: confirmation in a Hungarian sample. Mol Psychiatr 10, 861-67.

Sullivan, PF, de Geus, EJ, Willemsen, G, et al. (2009). Genome-wide association for major depressive disorder: a possible role for the presynaptic protein piccolo. Mol Psychiatry 14:359375.

Surtees, PG, Wainwright, NW, Willis-Owen, SA, Luben, R, Day, NE, Flint, J. (2006). Social adversity, the serotonin transporter (5-HTTLPR) polymorphism and major depressive disorder. Biol Psychiatry 59, 224-229.

Thapar, A, McGuffin, P. (1994). A twin study of depressive symptoms in childhood. Br J Psychiatry 165, 259-265.

Torner, L, Maloumby, R, Nava, G, Aranda, J, Clapp, C, Neumann, ID. (2004). In vivo release and gene upregulation of brain prolactin in response to physiological stimuli. Eur J Neurosci 19, 1601-1608.

Triozzi PL, Kinney P, Rinehart JJ. (1990). Central Nervous System Toxicity of Biological Response Modifiers. Ann NY Acad Sci 594, 347-354.

Tsai, SJ, Cheng, CY, Yu, YWY, Chen, J, Hong, CJ. (2003). Association study of a brain-derived neurotrophic factor genetic polymorphism and major depressive disorders, symptomatology, and antidepressant response, Am Journ Med Genet 123B, 19-22 
Verhagen, M, Meij, vd A, Deurzen, v PAM, Janzing, JGE, Arias-Vásquez, A, Buitelaar, JK, Franke, B. (2010). Meta-analysis of the BDNF Val66Met polymorphism in major depressive disorder: effects of gender and ethnicity. Mol Psychiatr 15, 260-71.

Wade, TJ, Cairney, J, Pevalin, DJ. (2002). Emergence of gender differences in depression during adolescence: National panel results from three countries. J Am Acad Child Adolesc Psychiatry 41:190-198.

Warner, V, Mufson, L, Weissman, MM. (1995). Offspring at high and low risk for depression and anxiety: mechanisms of psychiatric disorder. J Am Acad Child Adolesc Psychiatry 34, 786797.

Widlöcher, DJ. (1983). Psychomotor retardation: clinical, theoretical, and psychometric aspects. Psychiatr Clin North Am 6(1), 27-40.

Windle, RJ, Kershaw, YM, Shanks, N, Wood, SA, Lightman, SL, Ingram, CD. (2004). Oxytocin attenuates stress-induced c-fos mRNA expression in specific forebrain regions associated with modulation of hypothalamo-pituitary-adrenal activity. J Neurosci 24, 2974-2982.

Wu, S, Jia, M, Ruan, Y, Liu, J, Guo, Y, Shuang, M, et al. (2005). Positive association of the oxytocin receptor gene (OXTR) with autism in the Chinese Han population. Biol Psychiatry 58, 74-77.

Ylisaukko-oja, T, Alarcon, M, Cantor, RM, Auranen, M, Vanhala, R, Kempas, E et al. (2005). Search for autism loci by combined analysis of Autism Genetic Resource Exchange and Finnish families. Ann Neurol 59, 145-155.

Zetzsche, T, Frasch, A, Jirikowsi, G, Murck, H, Steiger, A. (1996). Nocturnal oxytocin secretion is reduced in major depression. Biol Psychiatry 39, 584. 
Figure 1. BDNF polymorphism. The courtesy of Ágnes Fehér.

Figure 2. Cellular transport and secretion of BDNF.From the article titled the Yin and yang of neurotrophin action by Bai Lu, Petti T. Pang \& Newton H. Woo (2005). Nature Reviews Neuroscience 6, 603-614. 
Appendix

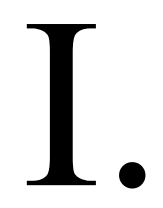




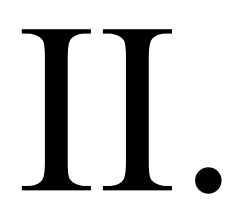




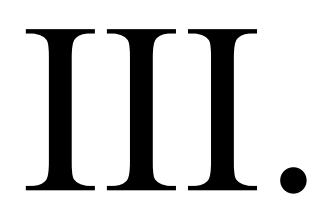

